\title{
QSIdb: quorum sensing interference molecules
}

Shengbo Wu $\mathrm{W}^{1,3,4}$, Chunjiang $\mathrm{Liu}^{1,3,4}$, Jie Feng ${ }^{2}$, Aidong Yang ${ }^{7}$, Fei Guo ${ }^{2 *}$, and Jianjun Qiao ${ }^{1,4,5,6 *}$

${ }^{1}$ School of Chemical Engineering and Technology, Tianjin University, Tianjin, 300072, China

2 School of Computer Science and Technology, College of Intelligence and Computing, Tianjin University, Tianjin 300350, China

${ }^{3}$ State Key Laboratory of Chemical Engineering, Tianjin University, Tianjin 300072, China

${ }^{4}$ Collaborative Innovation Center of Chemical Science and Engineering (Tianjin), Tianjin, 300072, China

${ }^{5}$ Key Laboratory of Systems Bioengineering, Ministry of Education (Tianjin University), Tianjin, 300072 , China

${ }^{6}$ Frontiers Science Center for Synthetic Biology (Ministry of Education), Tianjin University, Tianjin, 300072, China

${ }^{7}$ Department of Engineering Science, University of Oxford, Oxford OX1 3PJ, UK

* Correspondence and requests for materials should be addressed to J.Q. (email: jianjunq@tju.edu.cn) and Fei Guo (email: fguo@tju.edu.cn)

\begin{abstract}
Quorum sensing interference (QSI), the disruption and manipulation of quorum sensing (QS) in the dynamic control of bacteria populations could be widely applied in synthetic biology to realize dynamic metabolic control and develop potential clinical therapies. Conventionally, limited QSI molecules (QSIMs) were developed based on molecular structures or for specific QS receptors, which are in short supply for various interferences and manipulations of QS systems. In this study, we developed QSIdb (http://qsidb.Ibci.net/), a specialized repository of 633 reported QSIMs and 73,073 expanded QSIMs including both QS agonists and antagonists. We have collected all reported QSIMs in literatures focused on the modifications of $\mathrm{N}$-acyl homoserine lactones, natural QSIMs, and synthetic QS analogues. Moreover, we developed a pipeline with SMILES-based similarity assessment algorithms and dockingbased validations to mine potential QSIMs from existing 138,805,608 compounds in the PubChem database. In addition, we proposed a new measure, pocketedit, for assessing the similarities of active
\end{abstract}


protein pockets or QSIMs crosstalk, and obtained 273 possible potential broad-spectrum QSIMs. We provided user-friendly browsing and searching facilities for easy data retrieval and comparison. QSIdb could assist the scientific community in understanding QS-related therapeutics, manipulating QS-based genetic circuits in metabolic engineering, developing potential broad-spectrum QSIMs, and expanding new ligands for other receptors.

\section{Biographical Note}

Shengbo Wu is a PhD candidate at School of Chemical Engineering and Technology, Tianjin University, Tianjin, 300072, China. He has been working in the field of QS and QSI applications.

Chunjiang Liu is an associate professor at the State Key Laboratory of Chemical Engineering, Tianjin University, Tianjin 300072, China. His research interest is focused on system engineering of various networks, including cell-cell communications.

Jie Feng is a master candidate at School of Computer Science and Technology, College of Intelligence and Computing, Tianjin University, Tianjin 300350, China.

Aidong Yang is an associate professor at the Department of Engineering Science, University of Oxford, Oxford OX1 3PJ, UK. His research interest is focused on developing methods and tools for modelling chemical/biochemical processes and related systems, such as QS systems.

Fei Guo is an associate professor at the School of Computer Science and Technology, College of Intelligence and Computing, Tianjin University, Tianjin 300350, China. Her research interest is focused on comparative genomics and bioinformatics

Jianjun Qiao is a professor at the Key Laboratory of Systems Bioengineering, Ministry of Education (Tianjin University) and Frontiers Science Center for Synthetic Biology (Ministry of Education), Tianjin University, Tianjin, 300072, China. His research interest is focused on synthetic biology, applications of QS in metabolism regulation and potential medicine development.

Keywords: antibiotics, multidrug-resistant, quorum sensing analogues, quorum sensing interference, SMILES, AutoDock Vina. 


\section{Introduction}

Quorum sensing (QS), a microbial cell-to-cell communication process, dynamically regulates a variety of metabolism and physiological activities, such as biofilm formation, conjugation, competence, bacteriocin production, and pathogenesis [1]. QS signaling molecules, once produced by cells, diffuse into the culture medium freely. When the level of QS signaling molecules reaches a certain threshold, they will diffuse back into cells and be recognized by specific QS receptors to allow cells to sense their density and regulate the expression of downstream genes [2]. QS can be utilized for population-level control of bacteria and potential clinical therapies development based on autoinducers (Als) including acyl-homoserine lactones (AHLs) for Gram-negative bacteria [3], auto-inducing peptides (AIPs) for Gram-positive bacteria [4], autoinducer 2 (AI-2) [5] and indole [6] for interspecies communication. Underpinned by functions of Als and quorum sensing interference molecules (QSIMs), the disruptions and manipulations of QS can be widely applied in synthetic biology [7] to realize the dynamic metabolism control [8] and develop medicine for multidrug-resistant bacteria [9], such as Staphylococcus aureus [10] and Pseudomonas aeruginosa [11].

Various research studies have been conducted for developing QSIMs by screening or mimicking Als. The most typical method for screening QSIMs is using active reporters of Als to detect natural or synthesized compounds. Rasmussen et al. [12] constructed a collection of screening systems with lux and las QS devices, which enabled them to identify a number of novel QSIMs among natural and synthetic compound libraries, such as garlic extract and 4-nitro-pyridine-N-oxide (4-NPO). Müh et al. [13] developed an ultra-high-throughput cell-based assay (nanowell technology) to screen a library of approximately 200,000 synthetic molecules for inhibitors of LasR-dependent gene expression. Compared with traditional screening methods heavily dependent of verification experiments, computerbased virtual screening for natural QSIMs and synthesizing compounds as analogues of Als has attracted increasing attention due to its convenience and economy. Virtual screening for QSIMs can be based on either ligands such as AHLs [14] and Al-2 [15] or the structure of receptors such as LasR [16, 17], RhIR [16], LuxR [18], TraR [19], QscR [20], PqsR [21].

Some databases relevant to QS signaling molecules of Gram-negative and Gram-positive bacteria have been constructed for better understanding of various QS mechanisms. Rajput et al. [22] have constructed SigMol, which held various QS molecules for Gram-negative bacteria. Quorum sensing peptides (QSPs), signaling molecules used by Gram-positive bacteria, have also been collected and 
analyzed by Rajput et al. [23] in their QSPpred database. Many databases for proteins with ligand binding, such as TarFisDock [24], PSCDB [25], BioLiP [26], and PDID [27], have been constructed to provide important information for understanding interactions between target proteins and drug molecules. Antimicrobial peptides [28], being regarded as important templates for developing a new generation of antimicrobials, have been collected and summarized in some databases. Thakur et al. [29] collected 1,245 antiviral peptides for human viruses battle, such as HIV, to establish the AVPpred database. Wang et al [30] constructed the antimicrobial peptide database (APD), which contains 3,142 antimicrobial peptides from six kingdoms. Rajput et al. [31] have completed a summary for biofilm inhibition named "aBiofilm", which contains 5,027 anti-biofilm agents. However, there is no database specifically for QSIMs. Due to the current dramatic increase in drug-resistant bacteria and the decline in the availability of new antibiotics, a database for QSIMs is necessary and urgent. In addition, currently reported molecules with QSI activity are relatively limited, and it is highly desirable to mine potential QSIMs from the existing small molecules based on the reported QSIMs.

Based on the reported QSIMs in literatures and some available database, such as PubChem [32], ChEMBL [33], Reaxys [34], and Zinc [35], we have collected 633 QSIMs to construct a small virtual library including natural and synthetic agonists and antagonists for various QS systems. An edit distance of the Simplified Molecular Input Line Entry System (SMILES) [36] of reported QSIMs was used to create a non-redundant set of ligands to reduce the total computational workload. We developed a pipeline with SMILES-based similarity assessment algorithms and docking-based validations to mine the potential QSIMs from existing 138,805,608 compounds in the PubChem database. To validate the QSI activity of the screened 73,073 molecules, we have docked them with nine typical QS receptors (SmcR, TraR, LasR, CviR, QscR, SdiA, PqsR, LuxP, and LsrB) by AutoDock Vina software [37] and ranked them according to their free binding energies (FBEs). In addition, we proposed a new measure, namely pocketedit, for the similarity calculation of active protein pockets or QSIMs crosstalk, and developed the potential broad-spectrum QSIMs for multiple QS receptors. Finally, we obtained 273 potential broad-spectrum QSIMs for nine QS receptors based on analysis of pocketedit and the potential QSIMs distributions. QSIdb, a specialized database of the reported and potential quorum sensing interference molecules, has been constructed for browsing and searching data friendly and conveniently at websever http://qsidb.lbci.net/.

\section{Methods and materials}




\section{Data}

QS can be utilized to control the expression of groups of genes in a cell-density-dependent manner [38]. Generally, Gram-negative bacteria use AHLs, 2-heptyl-3-hydroxy-4-quinolone (PQS) and diffusible signal factors (DSFs) as autoinducers for intracellular communication [3]. The signals for intercellular communication are mainly Al-2 [39-41] and indole [42], which can regulate the cooperation or competition in various microbial communities. Except the AIPs and antimicrobial peptides for Grampositive bacteria, the reported QSIMs mainly includes the modifications of the acyl-chain and lactonering for AHLs, natural QSIMs from various organism, synthetic analogues of CAI-1 (cholera autoinducer 1), DKPs (Diketopiperazines), HAQs(4-hydroxy-2-alkylquinolines), DSFs, Al-2 and indole.

\section{Data acquisition}

We have investigated and collected QS signals and QSIMs stated above for various QS systems from many literatures and several online databases, such as PubChem [32], ChEMBL [33], Reaxys [34], and Zinc [35]. The nine typical QS receptors with existing crystal structures, i.e. SmcR (3KZ9), TraR (1L3L), LasR (2UV0), CviR (3QP1), QscR (3SZT), SdiA (4Y15), PqsR (4JVD), LuxP (1JX6), and LsrB (1TJY), are from the Protein Data Bank (PDB) [43].

\section{SMILES-based virtual screening for expanded QSIMs}

Chemical similarity search is a fundamental technique for ligand-based drug discovery [44]. In this study, similarity-based virtual screening is firstly used to mine the potential QSIMs from existing compounds. Note that converting an existing molecule structure into chemical information applicable for potential QSIMs development requires similarity analysis from chemical descriptor. Generally, there are onedimensional (SMILES, [45]), two-dimensional (Mold² [46]), three-dimensional (GETAWAY, [47]), and four-dimensional (GRID, [48]) chemical descriptors of molecules [49]. SMILES describes molecular structure in the form of strings, and has been applied to chemical properties prediction [50], virtual screening [51], quantitative structure-activity relationship (QSAR) modelling [52, 53], drug-target interaction prediction [54], and machine learning-based drug design [55]. Here, SMILES is applied to the similarity-based virtual screening for the development of potential QSIMs for the first time. The specific SMILES-based similarity calculations are based on the edit distance [54] and LINGO [56].

\section{Edit distance}

Edit distance is one of the most widely used measures to conduct comparison between strings. The edit distance between strings $\mathrm{S} 1$ and $\mathrm{S} 2$ is the minimum number of edit operations, such as insertion, 
deletion, and substitution for converting S1 to $\mathrm{S} 2$ [54]. The edit distance similarity is calculated as follows:

$$
\operatorname{Edit} S(S 1, S 2)=1-\frac{\operatorname{edit}(S 1, S 2)}{\operatorname{Max}(\text { length }(S 1), \text { length }(S 2))}
$$

Having observed significant redundancy (i.e. high similarities) in a subset of the 633 reported molecules and with an aim to reduce the computational burden, we carried out a de-redundancy process with the edit distance cutoff being 0.6. According to the distribution of similarities for different distance cutoffs shown in Fig. S3, the non-redundant dataset of 142 ligands with this cutoff threshold includes most of the molecules with low SMILES similarities, while maintaining a medium computational workload.

\section{LINGO}

Chemical linguistics with maximum common substructures, such as LINGO, are considered widely in quantifying molecular similarity, and they can be used as the computerized linguistics in comparing and searching through large text collections [57]. LINGO is based on the fragmentation of SMILES strings into overlapping substrings of defined sizes, which was developed by Vidal et al. [56]. Note that the LINGO profile is only related to the $q$ value of LINGO and its corresponding occurrence number and does not depend on the order of LINGO occurrence in a SMILES string. LINGO-based similarity between $\mathrm{S} 1$ and $\mathrm{S} 2$ is calculated as follows:

$$
\text { LINGOsim }=\frac{\sum_{i=1}^{m} 1-\frac{\left|N_{S 1, i}-N_{s 2, i}\right|}{\left|N_{S 1, i}+N_{S 2, i}\right|}}{m}
$$

where $m$ is the total number of unique LINGO created from S1 and S2. $N_{\mathrm{S} 1, \mathrm{i}}$ and $N_{\mathrm{S} 2, \mathrm{i}}$ represent the frequency of LINGO of type $i$ in S1 and S2, respectively.

The LINGO formats in common use are LINGO3, LINGO4, and LINGO5 with $q$ being 3, 4, and 5, respectively. This work established that virtual screening with LINGO3 for each non-redundant reported QSIMs from PubChem database is more flexible in SMILES-based structure similarity, and it can get more potential QSIMs than LINGO4 and LINGO5. Therefore, the LINGO length was fixed as $q=3$. In addition, to reduce the computational workload for docking-based validations by AutoDock Vina, the final cutoff for LINGO3 was set to 0.7. Based on the SMILES of the reported 142 QSIMs in the nonredundant dataset I, we developed a pipeline with SMILES-based algorithms and docking-based validations to mine potential QSIMs with creating a dataset II containing 73,073 compounds from existing 138,805,608 compounds (Fig. 1). 
(Fig. 1)

\section{Docking-based validation by AutoDock Vina}

AutoDock Vina is a software tool for docking calculations based on a simple scoring function and fast gradient optimization conformation search [37]. A series of pretreatments are required for receptors and ligands before docking. As an example, pretreatments for 3-oxo-C12-HSL (las AHL) and its QS receptor (LasR) are illustrated in Fig. 2. The strain A of 2 UV0 from PDB database was selected to be LasR, and subsequently water molecules and complexed ligands were removed from the strain A by Pymol [58]. Hydrogen atoms were added, and all atoms were set to be of the Assign AD4 type. KOLLMAN charges were taken into account during charge assignment with the help of AutoDockTools [59]. At the same time, 3-oxo-C12-HSL needed to be converted into a series of file formats (sdf, pdb, and pdbqt) with the help of a variety of software tools (Open babel [60], Raccon [61] or AutoDockTools [59]) to dock with LasR.

(Fig. 2)

Many species of Gram-negative bacteria communicate with kin and coordinate group behaviors through AHL QS systems. There are many reports of "promiscuous" receptors (LuxR, LasR, TraR) that respond broadly to nonself AHL signals [62]. It has been indicated that the promiscuous communications of the AHL QS systems suit well for the chemical similarity principle [44], which states that compounds and proteins with similar structures will probably have similar bioactivities. Therefore, an underlying assumption for our proposed SMILES-based virtual screening pipeline is that chemically similar QSIMs will bind to the same or similar QS receptors and vice-versa. Note that most of the reported QS receptors do not have existing crystal structures in the PDB database, except nine QS receptors (SmcR, TraR, LasR, CviR, QscR, SdiA, PqsR, LuxP, and LsrB) we collected. However, the homology modeling of QS receptors without crystal structures can be carried out based on the nine QS receptors stated above. As listed in Table 1, the binding sites for collected nine QS receptors are fixed for their Als and QSIMs. In addition, due to the missing of crystal structure of LuxR and the high conservatism of SmcR and LuxR [63], we represented LuxR with the crystal structure of $S m c R$, a transcriptional regulator from $V$. vulnificus (PDB: 3KZ9). We selected nine natural QS signals (C6HSL, C8HSL, C12HSL, 3OC6HSL, 30C8HSL, 3OC12HSL, PQS, S-THMF-borate, and R-THMF) to dock with nine QS receptors to verify the promiscuous QS communications, determine the FBEs cutoff used in separating binding and non- 
binding, and test the validity of docking-based approach. We applied a ligand (PubChem ID: 101776684), which has a high similarity with S-THMF-borate, to dock with QS receptors for nonerecognition of boron in the Vina software. With the help of the FBEs cutoffs, we ranked and analyzed the docking results for the expanded 73,073 ligands and nine QS receptors.

(Table 1)

\section{Protein pockets similarity or QSIMs crosstalk definition}

While the similarity of pockets with similar amino acid binding sites, such as the pockets of LasR, TraR, CviR, QscR, SdiA (Table 1) is relatively easy to quantify, deliberations are required for pockets with different binding sites such as SmcR and PqsR (Table 2). Here, we firstly performed a similarity analysis of the amino acid sequences for nine QS receptors. The distance analysis of the three-dimensional structures for receptors was then carried out on the root-mean-squared deviation (RMSD) scoring function [64]. RMSD measures the deviation of a target set of coordinates to a reference set of coordinates, with RMSD equal 0 indicating a perfect overlap. To deal with the protein pockets with different amino acid binding sites, we proposed a new similarity measure, termed pocketedit, based on the distribution of the docking FBEs, which is stated as follows:

$$
\text { pocketedit } x, y=\frac{N_{x y}}{N_{x}+N_{y}-N_{x y}}
$$

where $x$ and $y$ represent two different protein pockets, such as Als binding pockets of LasR and TraR. pocketedit $_{x, y}$ is the similarity between two different protein pockets. $N_{\mathrm{x}}, N_{\mathrm{y}}$ are the number of ligands that bind to $x$ and $y$ protein pockets, respectively. $N_{x y}$ is the number of ligands that bind to both $x$ and $y$ protein pockets.

The higher the similarity of pockets, the more significant the crosstalk of two receptors will be for QSIMs. Therefore, this equation can be used to calculate the similarity of pockets and also well represents the crosstalk degree of different receptors to QSIMs. As such, pocketedit could be instrumental for developing the drug-like QSIMs which can act on multiple QS receptors and which are termed as the broad-spectrum QSIMs in this work.

\section{Results}

\section{Reported QSIMs}

Based on a large number of literatures and various databases, 633 reported QSIMs have been collected 
corresponding to various QS receptors, i.e. LuxR (254), LasR (275), TraR (67), CviR (19), RhIR (28), LuxN (6), PhzR (8), QscR (15), PqsR (25), LuxP (42), LsrB (50) and other receptors (45). The analysis of the 633 reported QSIMs is conducted in two parts, namely the statistics and the docking-based validation.

\section{Statistics of reported QSIMs}

According to the specific distribution of 633 reported QSIMs on various QS receptors (Fig. 3a), SmcR (LuxR) from V. vulnificus and LasR from $P$. aeruginosa are the main targets of the reported QSIMs, followed by TraR (R. radiobacter), LsrB (S. typhimurium) and others. Among the collected QSIMs, there are 79 natural compounds from various organisms, accounting for $12.48 \%$ (Fig. 3b). Due to the small concentration produced and the toxicity of the natural QSIMs, more and more synthetic QSIMs have been developed gradually by modifying the original Als. For example, the development of synthetic QSIMs for interfering AHL QS systems is mainly focused on the modifications in the AHL side chain and the AHL ring moiety, which account for $31.91 \%$ and $35.55 \%$, respectively. Totally among the 633 reported QSIMs, AHL-based ligands account for the majority (71.57\%), followed by AI-2 analogues (13.43\%), natural QSIMs and PQS analogues (2.53\%).

The 633 QSIMs we have collected include QS agonists and QS antagonists. There are 267 QS antagonists and $62 \mathrm{QS}$ agonists (Fig. 3c) that have specific $I C_{50}$ values and $E C_{50}$ values, respectively. Furthermore, it is shown that 21 molecules can act as both QS agonists and QS antagonists for different QS receptors (Table 2). Note that the total number of the QSIMs for the receptors in Fig. 3a is more than 633, which means that there are some QSIMs crosstalk among different QS receptors. To better understand crosstalk, we analyzed the distribution of QSIMs for LuxR (SmcR), LasR, TraR, LuxP, and LsrB (Fig. 3d), which shows a certain degree of QSIMs crosstalk among LuxR (SmcR), LasR and TraR. Additionally, QSIMs crosstalk exists between LuxP and LsrB, too.

(Fig. 3), (Table 2)

\section{Docking results for reported QSIMs and receptors}

The distribution of docking free binding energies (FBEs) among the nine typical QS receptors and their natural corresponding Als is listed in the heatmap of Fig. 4a. The FBEs of six AHLs (C6HSL, C8HSL, C12HSL, 30C6HSL, 30C8HSL, 3OC12HSL) with different side chains and the reported AHL-binding QS receptors (SmcR, LasR, TraR, CviR, QscR, and SdiA) are with high similarities. It verified the 
existing QS signals crosstalk among the promiscuous AHL-based communications. Furthermore, it can be seen that the FBEs of six AHLs and AHL-binding receptors stated above are lower than $-6 \mathrm{kCal} / \mathrm{mol}$, except the FBE of C6-HSL and SmcR which is $-5.9 \mathrm{kCal} / \mathrm{mol}$. As intercellular signal molecules, STHMF-borate and R-THMF are often regarded as the non-binder to the AHL-binding receptors, and their FBEs to AHL-binding receptors are greater than $-6 \mathrm{kCal} / \mathrm{mol}$. Therefore, the FBEs cutoff used in separating binding and non-binding was set to $-6 \mathrm{kCal} / \mathrm{mol}$. It means that if the FBE is greater than -6 $\mathrm{kCal} / \mathrm{mol}$, there is little binding between the QS-based ligand and the receptor.

Note that the FBE of 101776684 and LuxP is $-9.3 \mathrm{kCal} / \mathrm{mol}$, which is much lower than $-6 \mathrm{kCal} / \mathrm{mol}$. As illustrated in Fig. 4b, the hydrogen bonding of protein LuxP and 101776684 includes Gln77, Ser79, Trp82, Asn159, Arg215, Thr266 and Arg310, which are included in the binding sites of LuxP and STHMF-borate (Table 2). Therefore, it is feasible to replace the S-THMF-borate with 101776684 to dock with LuxP. The FBEs of PQS to SmcR, LasR, TraR, CviR, QscR, and SdiA are -6.9, -9.8, -9.5, -9.0, 9.6, and $-8.7 \mathrm{kCal} / \mathrm{mol}$, respectively, which are lower than that of its original receptor (PqsR, -6.8 $\mathrm{kCal} / \mathrm{mol}$ ). This indicates that the bacteria with any of these six QS receptors, such as Vibrio fischeri, Chromobacterium violaceum, and Escherichia coli can respond to the PQS, which is one of the QS signals secreted by Pseudomonas aeruginosa. In addition, the distribution of FBEs involving LuxP and LsrB, two QS receptors for the intercellular communications, is rather different from that of seven other QS receptors for intracellular communications, which agrees well with the situation of real bacterial QS interactions. These results offer a validation of the docking-based approach and support its application for the screening of potential QSIMs.

(Fig. 4)

\section{Expanded QSIMs}

Similar to the analysis of the reported QSIMs, the results for expanded QSIMs are also reported in two parts: the statistics and the docking-based results.

\section{Statistics of expanded QSIMs}

The docking results for the potential QSIMs and nine QS receptors (SmcR, TraR, LasR, CviR, QscR, SdiA, PqsR, LuxP, and LsrB) are illustrated in Fig. 5. To categorize FBEs better, we set $-8 \mathrm{kCal} / \mathrm{mol}$ as another cutoff in separating strong and weak binding. As for SmcR, there are 3,029 ligands $(4.15 \%)$ which have FBEs lower than $-8 \mathrm{kCal} / \mathrm{mol}$, while the numbers of ligands for LasR, TraR, CviR, QscR, SdiA, and PqsR are 44,674 (61.14\%), 30,185 (41.31\%), 18,910 (25.88\%), 28,867 (39.5\%), 24,690 
(33.79\%), and 8,091 (11.07\%), respectively (Fig. 5 and Fig. S2). The fractions of FBEs ( $\leq-8 \mathrm{kCal} / \mathrm{mol})$ for LuxP and LsrB are $0.09 \%$ and $0 \%$, respectively, which are much lower than those of the above seven QS receptors. On the fractions of FBEs being greater than $0 \mathrm{kCal} / \mathrm{mol}$ (completely incapable of QSI), LsrB ranks first $(39,729,54.37 \%)$, followed by LuxP (16,459, 22.52\%), SdiA (7,275, 9.96\%), CviR $(1,165,1.59 \%)$, TraR $(1,137,1.56 \%)$, QscR $(674,0.92 \%)$, PqsR $(6,0.01 \%)$. With the help of the FBEs cutoffs being $-6 \mathrm{kCal} / \mathrm{mol}$ and $-8 \mathrm{kCal} / \mathrm{mol}$, we ranked the $\mathrm{FBEs}$ among the expanded 73,073 ligands and nine QS receptors.

(Fig. 5)

\section{Docking-based results for expanded QSIMs and receptors}

Based on the FBEs ranking of the expanded 73,073 ligands and nine QS receptors, we identified the ligands that bind most strongly to their corresponding QS receptors, which are listed in Fig. 6. The ligands 56324809, 101018536, 3424041, 20279703, 109057410, 118004297, 13782492, 131400990, and 45084042 (PubChem CID) have the lowest FBEs for binding to SmcR, TraR, LasR, CviR, QscR, PqsR, SdiA, LuxP, and LsrB, respectively. According to the FBEs distribution, it can be seen that there are serious QSIMs crosstalks among the nine molecules stated above and seven QS receptors (SmcR, LasR, TraR, CviR, QscR, PqsR and SdiA). The FBEs distribution of LuxP and LsrB is quite different from the other seven receptors. The specific binding sites of each QS receptor and the corresponding strongest binding ligands are shown in Fig. 6. The binding sites of LuxP and 131400990 include Ser79, Arg215, Thr266, Trp289 and Arg310, which are rather similar to those of 101776684 and LuxP (GIn 77, Ser79, Trp82, Asn159, Arg215, Thr266, Arg310) (Fig. 4b). This suggests that structurally the 131400990 has a significant potential to be one of the QSIMs for LuxP receptor.

(Fig. 6)

\section{Data retrieval}

\section{Browse}

A user-friendly 'BROWSE' option allows to explore the QSIMs data by two-tiers: the reported QSIMs and the extended QSIMs (Fig. 7). For the reported QSIMs, a separate browse option is provided where the visualized data can be sought by the type of molecules, such as AHLs, acyl-chain modifications for AHLs, lactone-ring modifications for AHLs, PQS analogues, Al-2 analogues and natural QSIMs. 
For the expanded QSIMs, another separate browse option is provided where the visualized data can be sought by the receptors, such as LasR and TraR. The users can choose required categories for further details. For a better browsing experience, a drop-down menu is added to filter ligands according to their FBEs range. In addition, we added the PubChem database links for the reported and the extended QSIMs to make it easier to obtain the detailed chemoinformatic description.

(Fig. 7)

\section{Search}

QSIdb includes "SEARCH" and "EXPAND" searching facilities for the reported and expanded QSIMs, respectively. 'SEARCH' is provided to query some reported QSIMs according to different options: ALL, Category (molecular type of ligands), PubChem CID, QS receptors or SMILES. The output displays information of the reported QSIMs, fielded by PubChem CID, Binding protein for antagonists, Receptor for agonists, SMILES, and ligand type (Category). 'EXPAND' is provided to query extended QSIMs according to different fields: PubChem CID, SMILES of ligands or the QS receptors (Fig. 8). For a better searching experience, a drop-down menu is added to filter ligands according to their FBEs range. Output displays information of potential QSIMs, fielded by PubChem ID, SMILES, FBEs, Ki (inhibitor constant of the enzyme-inhibitor complex, $\mu \mathrm{M}), K \mathrm{~d}$ (dissociation constant, $\mu \mathrm{M})$, and $\mathrm{IC}_{50}\left(\mathrm{EC}_{50}\right)$ for nine QS receptors. To make it more convenient for getting the detailed chemoinformatic description, we added the PubChem database links for the reported and extended QSIMs. The users can specify any field against which one wishes to search, or else keep the default 'all' option which will search against all fields in the database. Besides the option to choose the fields, search type allows to retrieve either an exact match or the match containing query.

(Fig. 8)

\section{Discussion}

We conducted similarity analysis on the amino acid sequences and three-dimensional structures for nine QS receptors, both reflecting the features of the entire proteins, which are not necessarily always suitable for identifying potential QSIMs. For example, the amino acid sequence and three-dimensional structure similarities of SmcR and PqsR are 0.07 and 12.41 (RMSD distance), respectively (Fig. S1a and Fig. S1b). It means that both amino acid sequence and the three-dimensional structure similarities 
of SmcR and PqsR are relatively low. However, as illustrated in Fig. 5, there is a considerable similarity between the FBEs distributions of SmcR and PqsR receptors. In this work, we proposed and applied pocketedit (equation 3 ) to analyze the similarity of the receptor pockets with different amino acid binding sites. LasR leads among the nine proteins with 67,359 potential active ligands (FBEs lower than -6 kcal/mol), followed by QscR (63,345), TraR (62,184), PqsR (61,320), CviR $(58,237)$, SdiA $(53,011)$, SmcR $(48,949)$, LuxP $(16,785)$ and LsrB $(2,329)$ (Fig. 9a). The number of ligands binding nine receptors was calculated pairwisely, and the results of pocketedit for various pairwise are shown in Fig. 9b. Note that the amino acid binding sites of the pockets of two receptors ( $\mathrm{SmcR}$, PqsR) are different from those of five receptors (LasR, TraR, CviR, QscR and SdiA) (Table 1), but they have quite similar FBEs distributions (Fig. 5) and pocketedit values (Fig. 9b). Therefore, different receptors with low similarities in amino acid sequences and three-dimensional structures can have high similarities in binding pockets, such as SmcR and PqsR. The similarity of protein pockets can be characterized by the similarity of binding ligands distribution and even calculated by the pocketedit.

(Fig. 9)

Pocketedit can be applied to calculate and analyze the similarity of protein pockets as well as the crosstalk of QSIMs for various QS receptors. The higher the pocketedit is, the higher degree the crosstalk of two receptors will be of. In the QS-based applications for the dynamic control of microbial consortia, most researchers hope to eliminate QS crosstalk to obtain orthogonal QS systems. However, more attentions should be paid to those QSIMs with higher crosstalk for multiple targets (receptors) to develop broad-spectrum QSIMs. In order to obtain the potential broad-spectrum QSIMs for nine QS receptors, we analyzed the pocketedits and the distributions of 73,073 ligands, and obtained 273 potential broad-spectrum QSIMs (Table S1). Ten of them are listed in Table 3, which are expected to be verified by experiments in the future.

\section{(Table 3)}

To reduce the computational workload and save time, SMILES-based similarity assessment is based on the simple similarity calculation method, such as edit distance or LINGO3, in the pipeline to screen the potential QSIMs from the PubChem database. The cutoff should be set as an appropriate value $(0.7$ for LINGO3 in this study) based on the analyzation of the simulation results distribution with different 
cutoffs. Recently, several evolved SMILES-based representations have been reported, such as SMILES2Vec [50], Mol2Vec [55], FP2Vec [53], which have combined with the machine learning techniques to predict the properties of the potential molecules. These evolved SMILES-based representations could be applied in our pipeline for the screening of the potential QSIMs with low sequence but high functional similarities from a much smaller database. In addition, to improve the accuracy and diversity of the chemical similarity-based virtual screening, some other chemical descriptors (e.g. 3D [47] or 4D [48]) and fingerprints (e.g. ECFP [65]) can be applied in our pipeline to mine the potential QSIMs.

\section{Conclusion}

Quorum sensing interference (QSI) is an effective strategy to deal with infection and disease caused by various pathogenic or even multidrug-resistant bacteria. QSI can also be applied in synthetic biology to realize the population-level control of bacteria. QSIdb is a comprehensive resource of the reported and potential QSI molecules (QSIMs). There are 633 reported QSIMs in QSIdb, which can be searched conveniently by protein types or ligand types, out of which 308 QSIMs have specific $I C_{50}$ values or $E_{50}$ values. Based on the SMILESs of the non-redundant dataset (containing 142 reported QSIMs), we developed a pipeline with SMILES-based algorithms and docking-based validations to create a potential QSIMs dataset (73,073 compounds) from the existing 138,805,608 compounds in the PubChem database. With the help of the FBEs cutoff, we ranked and analyzed the docking results among the expanded 73,073 ligands and nine QS receptors. In addition, pocketedit as a new measure we proposed for receptor pockets similarity calculation or QSIMs crosstalk evaluation will do much help in developing the potential multi-target QSIMs. Thus, we obtained 273 potential broad-spectrum QSIMs for nine QS receptors based on the analysis of the pocketedit values and the potential QSIMs distributions. Here, most QSIMs have been collected and integrated in our platform that can accelerate the research in field of quorum quenching therapeutics, superbug therapy without antibiotics, potential broad-spectrum QSIMs development and population-level control of bacteria. Researchers can explore the ligands listed in our collection and test them by experiments to understand the complex patterns of QS networking and contribute to various applications. 


\section{Key Points}

- QSIdb, a database of 633 reported and 73,073 potential QSIMs, is carefully constructed focusing on the modifications and synthetic analogues of various autoinducers for the typical QS receptors.

- The ligands regarded as both agonists and antagonists with specific concentrations are carefully curated in QSIdb for the first time.

- A pipeline with SMILES-based algorithms and docking-based validations is developed to mine the potential QSIMs from the existing 138,805,608 compounds.

- pocketedit is proposed as a new measure to calculate receptor pockets similarity and evaluate QSIMs crosstalk.

- 273 possible potential broad-spectrum QSIMs are obtained for nine QS receptors.

\section{Data availability}

QSIdb, a database of 633 reported and 73,073 potential quorum sensing interference molecules for various QS systems, which is freely available at: (http://qsidb.lbci.net/).

We will continuously update the database QSIdb.

The data are available from the corresponding author upon request with email.

\section{Supplementary data}

Supplementary Data will be available online.

\section{Acknowledgements}

This study was supported by the National Key Research and Development Project of China (2017YFD0201400), the National Natural Science Foundation of China $(31570089,31770076$, 61772362), and the Funds for Creative Research Groups of China (21621004), Dr. Jianjun Qiao was supported by The New Century Outstanding Talent Support Program, Education Ministry of China.

\section{Conflict of interest}

The authors declare no competing financial interests. 


\section{References}

1. Wu S, Liu J, Liu C, et al. Quorum sensing for population-level control of bacteria and potential therapeutic applications. Cell Mol Life Sci 2020;77:1319-43.

2. Wang S, Payne GF, Bentley WE. Quorum sensing communication: molecularly connecting cells, their neighbors, and even devices. Annu Rev Chem Biomol Eng 2020;11:447-68.

3. Papenfort K, Bassler BL. Quorum sensing signal-response systems in Gram-negative bacteria. Nat Rev Microbiol 2016;14:576-88.

4. Monnet V, Juillard V, Gardan R. Peptide conversations in Gram-positive bacteria. Crit Rev Microbiol 2014;42:339-51.

5. Xavier KB, Bassler BL. Interference with Al-2-mediated bacterial cell-cell communication. Nature 2005;437:750-53.

6. Lee $\mathrm{JH}$, Lee J. Indole as an intercellular signal in microbial communities. FEMS Microbiol Rev 2010;34:426-44.

7. Stephens K, Bentley WE. Synthetic biology for manipulating quorum sensing in microbial consortia. Trends Microbiol 2020. DOI: 10.1016/j.tim.2020.03.009.

8. Gupta A, Reizman IM, Reisch CR, et al. Dynamic regulation of metabolic flux in engineered bacteria using a pathway-independent quorum-sensing circuit. Nat Biotechnol 2017;35:273-79.

9. Zhao X, Yu Z, Ding T. Quorum-sensing regulation of antimicrobial resistance in bacteria. Microorganisms 2020;8:425-46.

10. Piewngam $\mathrm{P}$, Zheng $\mathrm{Y}$, Nguyen $\mathrm{TH}$, et al. Pathogen elimination by probiotic Bacillus via signalling interference. Nature 2018;562:532-37.

11. O'Loughlin CT, Miller LC, Siryaporn A, et al. A quorum-sensing inhibitor blocks Pseudomonas aeruginosa virulence and biofilm formation. Pnas 2013;110:17981-86.

12. Rasmussen TB, Bjarnsholt T, Skindersoe ME, et al. Screening for quorum-sensing inhibitors (QSI) by use of a novel genetic system, the QSI selector. J Bacteriol 2005;187:1799-14.

13. Müh U, Schuster M, Heim R, et al. Novel Pseudomonas aeruginosa quorum-sensing inhibitors identified in an ultra-high-throughput screen. Antimicrob Agents Chemother 2006;50:3674-79.

14. Geske GD, Wezeman RJ, Siegel AP, et al. Small molecule inhibitors of bacterial quorum sensing and biofilm formation. J Am Chem Soc 2005;127:12762-63.

15. Zhu P, Li M. Recent progresses on Al-2 bacterial quorum sensing inhibitors. Curr Med Chem 2012;19:174-86.

16. Annapoorani A, Umamageswaran V, Parameswari R, et al. Computational discovery of putative quorum sensing inhibitors against LasR and RhIR receptor proteins of 
Pseudomonas aeruginosa. J Comput Aided Mol Des 2012;26:1067-77.

17. Kalia M, Singh PK, Yadav VK, et al. Structure based virtual screening for identification of potential quorum sensing inhibitors against LasR master regulator in Pseudomonas aeruginosa. Microb Pathog 2017;107:136-43.

18. Soulere L, Sabbah M, Fontaine F, et al. LuxR-dependent quorum sensing: computer aided discovery of new inhibitors structurally unrelated to $\mathrm{N}$-acylhomoserine lactones. Bioorg Med Chem Lett 2010;20:4355-58.

19. Liu HB, Kim JS, Park S. Development and comparison of whole-cell assay systems for quorum-sensing inhibitors based on TraR, LasR, and QscR. J Biomol Screen 2011;16:986-94.

20. Hai-Bo L, Joon-Hee L, Kim JS, et al. Inhibitors of the Pseudomonas aeruginosa quorum-sensing regulator, QscR. Biotechnol Bioeng 2010;106:119-26.

21. Ilangovan $A$, Fletcher $M$, Rampioni $G$, et al. Structural basis for native agonist and synthetic inhibitor recognition by the Pseudomonas aeruginosa quorum sensing regulator PqsR (MvfR). PLoS Pathog 2013;9:e1003508.

22. Rajput A, Kaur K, Kumar M. SigMol: repertoire of quorum sensing signaling molecules in prokaryotes. Nucleic Acids Res 2016;44:634-39.

23. Rajput A, Gupta AK, Kumar M. Prediction and analysis of quorum sensing peptides based on sequence features. PLoS One 2015;10:e0120066.

24. Li H, Gao Z, Kang L, et al. TarFisDock: a web server for identifying drug targets with docking approach. Nucleic Acids Res 2006;34:W219-24.

25. Amemiya T, Koike R, Kidera A, et al. PSCDB: a database for protein structural change upon ligand binding. Nucleic Acids Res 2012;40:D554-58.

26. Yang J, Roy A, Zhang Y. BioLiP: a semi-manually curated database for biologically relevant ligand-protein interactions. Nucleic Acids Res 2013;41:D1096-103.

27. Wang C, Hu G, Wang K, et al. PDID: database of molecular-level putative protein-drug interactions in the structural human proteome. Bioinformatics 2016;32:579-86.

28. Fernandes FC, Rigden DJ, Franco OL. Prediction of antimicrobial peptides based on the adaptive neuro-fuzzy inference system application. Biopolymers 2012;98:280-87.

29. Thakur N, Qureshi A, Kumar M. AVPpred: collection and prediction of highly effective antiviral peptides. Nucleic Acids Res 2012;40:W199-204.

30. Wang G, Li X, Wang Z. APD3: the antimicrobial peptide database as a tool for research and education. Nucleic Acids Res 2016;44:D1087-93.

31. Rajput A, Thakur A, Sharma $S$, et al. aBiofilm: a resource of anti-biofilm agents and their potential implications in targeting antibiotic drug resistance. Nucleic Acids Res 2018;46:D894-D900.

32. Kim S, Thiessen PA, Bolton EE, et al. PubChem substance and compound databases. Nucleic Acids Res 2016;44:D1202-13. 
33. Gaulton A, Hersey A, Nowotka M, et al. The ChEMBL database in 2017. Nucleic Acids Res 2017;45:D945-D54.

34. Goodman J. Computer software review: Reaxys. J Chem Inf Model 2009;49:2897-98.

35. Shoichet B, Irwin J. ZINC - A free database of commercially available compounds for virtual screening. J Chem Inf Model 2005;45:177-82.

36. Weininger D. SMILES, a chemical language and information system. 1. Introduction to methodology and encoding rules. J Chem Inf Comput Sci 1988;28:31-36.

37. Trott O, Olson AJ. AutoDock Vina: improving the speed and accuracy of docking with a new scoring function, efficient optimization, and multithreading. $J$ Comput Chem 2010;31:455-61.

38. Goo E, An JH, Kang $\mathrm{Y}$, et al. Control of bacterial metabolism by quorum sensing. Trends Microbiol 2015;23:567-76.

39. Bassler BL, Wright M, Showalter RE, et al. Intercellular signalling in Vibrio harveyi: sequence and function of genes regulating expression of luminescence. Mol Microbiol 1993;9:773-86.

40. Chen X, Schauder S, Potier N, et al. Structural identification of a bacterial quorumsensing signal containing boron. Nature 2002;415:545-49.

41. Sedlmayer F, Hell D, Muller M, et al. Designer cells programming quorum-sensing interference with microbes. Nat Commun 2018;9:1822-35.

42. Lee JH, Wood TK, Lee J. Roles of Indole as an Interspecies and Interkingdom Signaling Molecule. Trends Microbiol 2015;23:707-18.

43. Berman HM, Westbrook J, Feng Z, et al. The Protein Data Bank. Nucleic Acids Res 2000;106:149-58.

44. Lo YC, Rensi SE, Torng W, et al. Machine learning in chemoinformatics and drug discovery. Drug Discov Today 2018;23:1538-46.

45. Ozturk H, Ozkirimli E, Ozgur A. A novel methodology on distributed representations of proteins using their interacting ligands. Bioinformatics 2018;34:i295-i303.

46. Hong $\mathrm{H}$, Xie $\mathrm{Q}, \mathrm{Ge} \mathrm{W}$, et al. Mold(2), molecular descriptors from 2D structures for chemoinformatics and toxicoinformatics. J Chem Inf Model 2008;48:1337-44.

47. Saiz-Urra L, Gonzalez MP, Fall Y, et al. Quantitative structure-activity relationship studies of HIV-1 integrase inhibition. 1. GETAWAY descriptors. Eur J Med Chem 2007; 42:64-70.

48. Ash J, Fourches D. Characterizing the chemical space of ERK2 kinase inhibitors using descriptors computed from molecular dynamics trajectories. J Chem Inf Model 2017; 57:1286-99.

49. Rognan D. Chemogenomic approaches to rational drug design. $\mathrm{Br} J$ Pharmacol 2010;152:38-52.

50. Goh G, Hodas N, Siegel C, et al. SMILES2Vec: an interpretable general-purpose deep 
neural network for predicting chemical properties. arXiv preprint 2017;arXiv:1712.02034. DOI: 10.475/123_4.

51. Miljkovic F, Rodriguez-Perez R, Bajorath J. Machine learning models for accurate prediction of kinase inhibitors with different binding modes. J Med Chem 2019. DOI: 10.1021/acs.jmedchem.9b00867.

52. Toropov AA, Benfenati E. SMILES in QSPR/QSAR Modeling: results and perspectives. Curr Drug Discov Technol 2007;4:77-116.

53. Jeon W, Kim D. FP2VEC: a new molecular featurizer for learning molecular properties. Bioinformatics 2019;35:4979-85.

54. Ozturk H, Ozkirimli E, Ozgur A. A comparative study of SMILES-based compound similarity functions for drug-target interaction prediction. BMC Bioinformatics 2016;17:128-39.

55. Jaeger S, Fulle S, Turk S. Mol2vec: unsupervised machine learning approach with chemical intuition. J Chem Inf Model 2018;58:27-35.

56. Vidal D, Thormann M, Pons M. LINGO, an efficient holographic text based method to calculate biophysical properties and intermolecular similarities. J Chem Inf Model 2005;45:386-93.

57. Wozniak M, Wolos A, Modrzyk U, et al. Linguistic measures of chemical diversity and the "keywords" of molecular collections. Sci Rep 2018;8:7598.

58. Delano WL. The PyMol molecular graphics system. Protns Structure Function Bioinformatics 2002;30:442-54.

59. Morris GM, Ruth H, William L, et al. AutoDock4 and AutoDockTools4: Automated docking with selective receptor flexibility. J Comput Chem 2010;30:2785-91.

60. O'Boyle NM, Banck M, James CA, et al. Open Babel: An open chemical toolbox. J Cheminform 2011;3:33-47.

61. Forli S, Huey R, Pique ME, et al. Computational protein-ligand docking and virtual drug screening with the AutoDock suite. Nat Protoc 2016;11:905-19.

62. Wellington S, Greenberg EP. Quorum sensing signal selectivity and the potential for interspecies cross talk. mBio 2019;10:e00146-19.

63. Rajamanikandan S, Jeyakanthan J, Srinivasan P. Binding mode exploration of LuxRthiazolidinedione analogues, e-pharmacophore-based virtual screening in the designing of LuxR inhibitors and its biological evaluation. J Biomol Struct Dyn 2017;35:897-916.

64. Roe DR, Cheatham TE, 3rd. PTRAJ and CPPTRAJ: Software for processing and analysis of molecular dynamics trajectory data. J Chem Theory Comput 2013;9:308495.

65. Rogers D, Hahn M. Extended-connectivity fingerprints. J Chem Inf Model 2010;50:74254. 


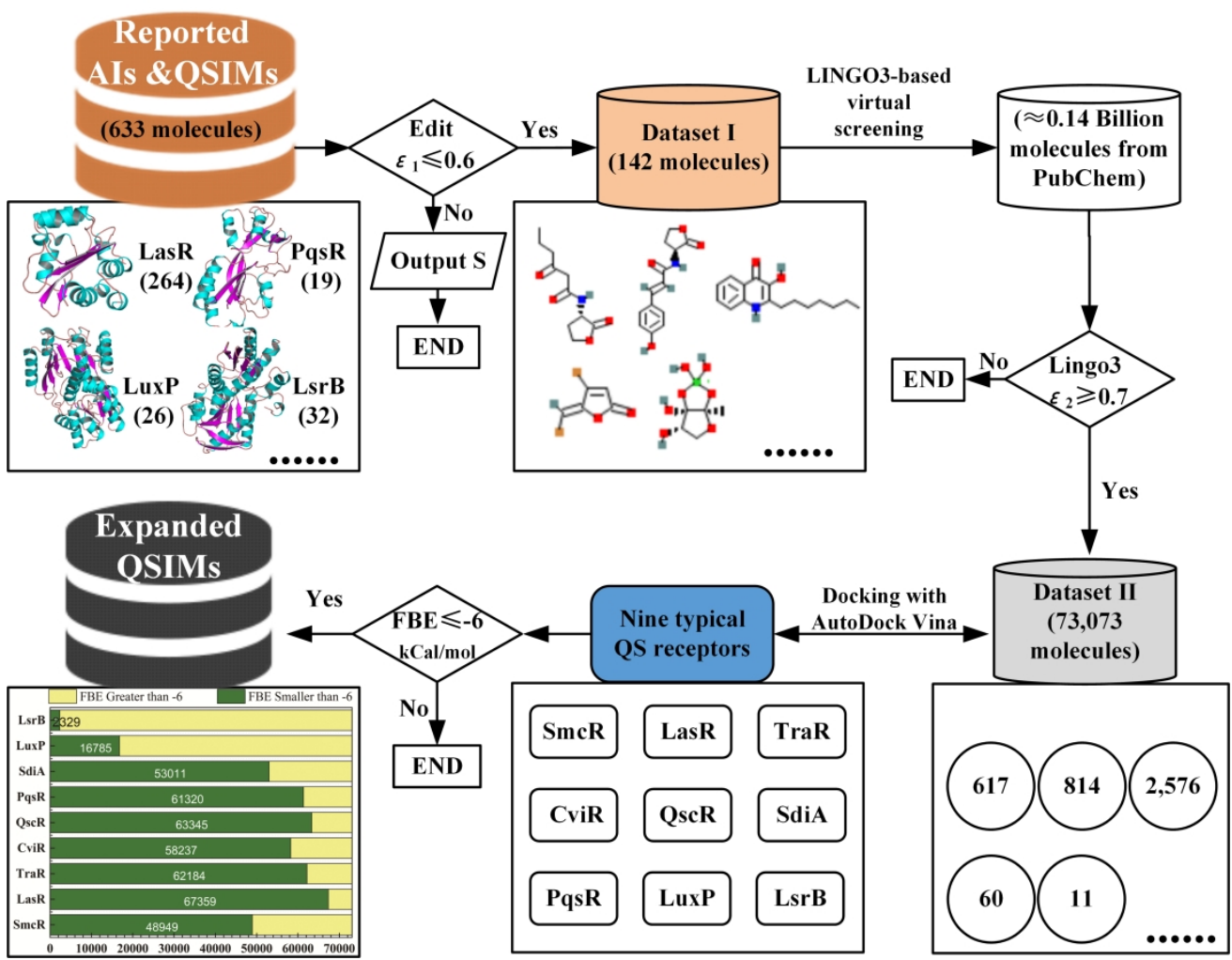

Fig. 1. Schematic diagram of the virtual screening pipeline for developing potential QSIMs $189 \times 148 \mathrm{~mm}(600 \times 600 \mathrm{DPI})$ 

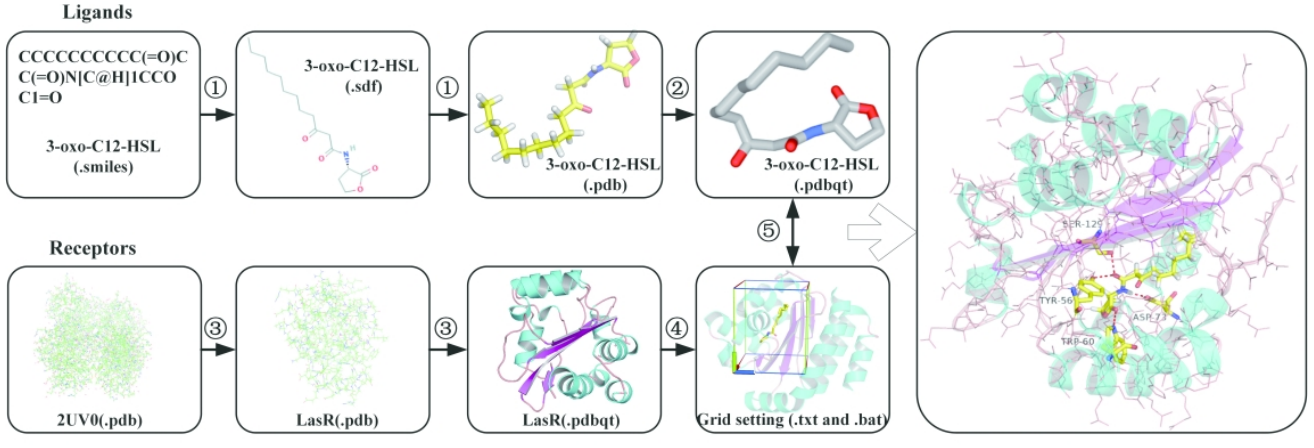

Software: (1)Openbabel; (2)Raccoon; (3)Pymol; (4)AutoDockTools; (5)AutoDock Vina

Fig 2. Flowsheet for dealing with receptors and ligands $178 \times 67 \mathrm{~mm}(1000 \times 1000 \mathrm{DPI})$ 


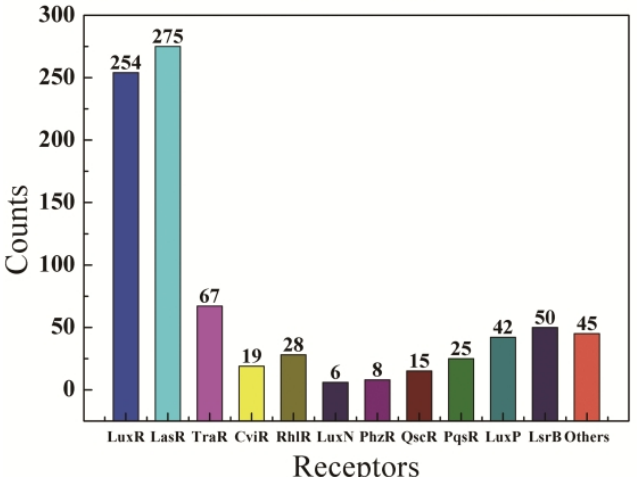

(a)

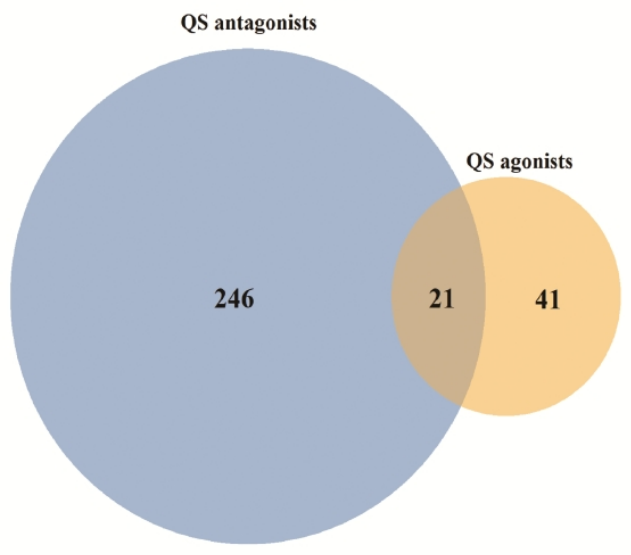

(c)

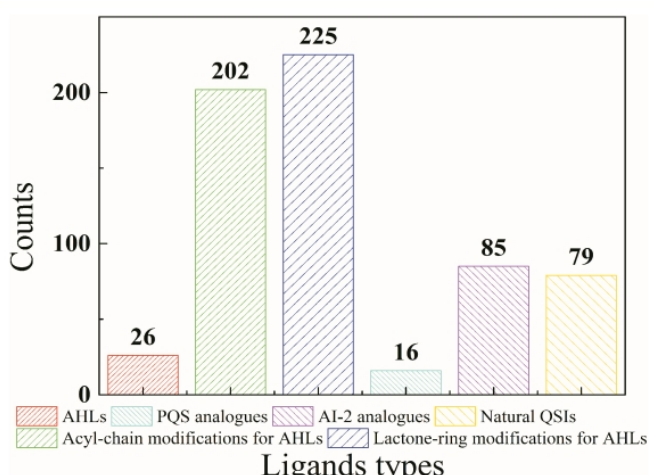

(b)

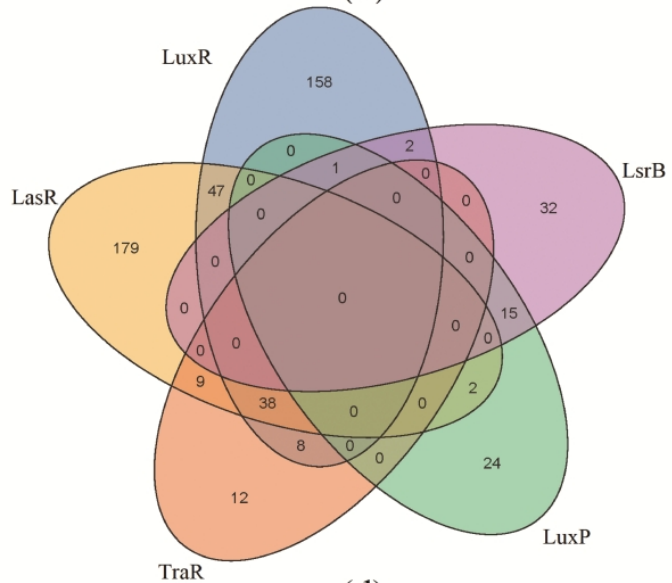

(d)

Fig. 3. Statistics of the reported QSIMs. (a) The distribution and counts of ligands on various QS receptors (LuxR, LasR, TraR, CviR, RhIR, LuxN, PhzR, QscR, PqsR, LuxP, LsrB, and other receptors); (b) The distribution and percent of ligands on their own type. (c) Distribution for QS agonists and QS antagonists. (d) QSIMs crosstalk analysis on the QSIMs distributions of five proteins (LuxR, LasR, TraR, LuxP, and LsrB).

$174 \times 152 \mathrm{~mm}(600 \times 600 \mathrm{DPI})$ 


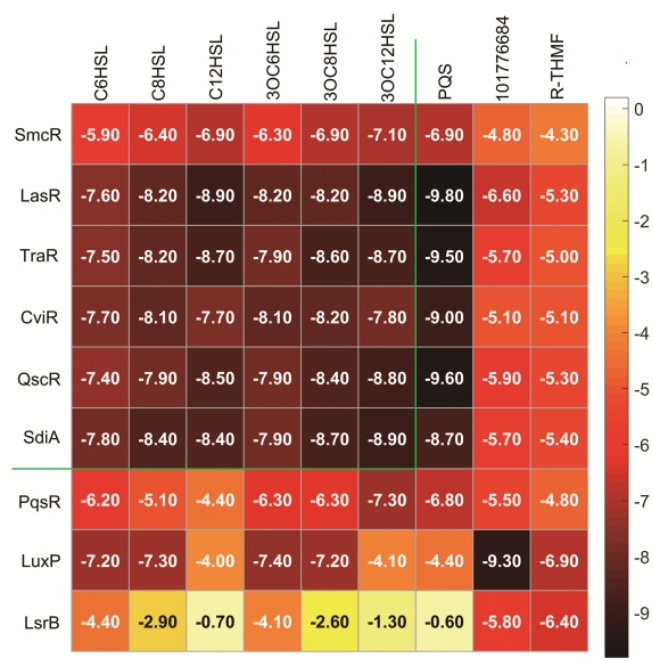

(a)

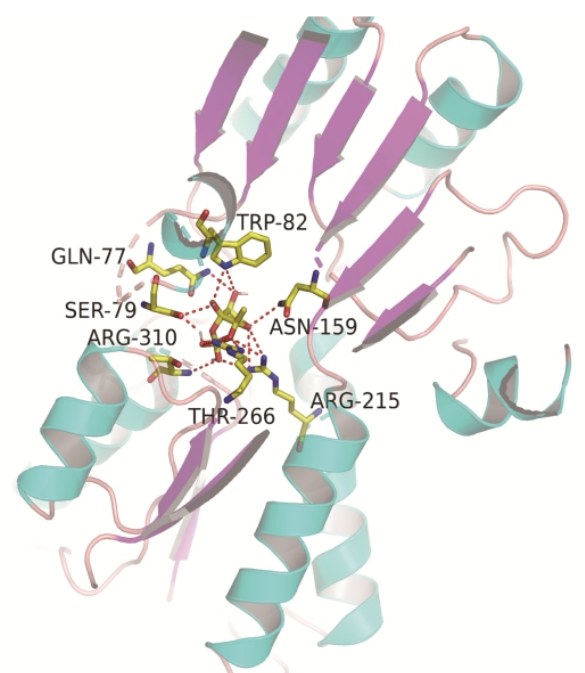

(b)

Fig. 4. FBEs results for the reported QSIMs and QS receptors. (a) FBEs heat map for the nine typical QS receptors and their corresponding ligands; (b) Hydrogen bonding of LuxP and the 101776684 molecule.

$178 \times 95 \mathrm{~mm}(600 \times 600 \mathrm{DPI})$ 

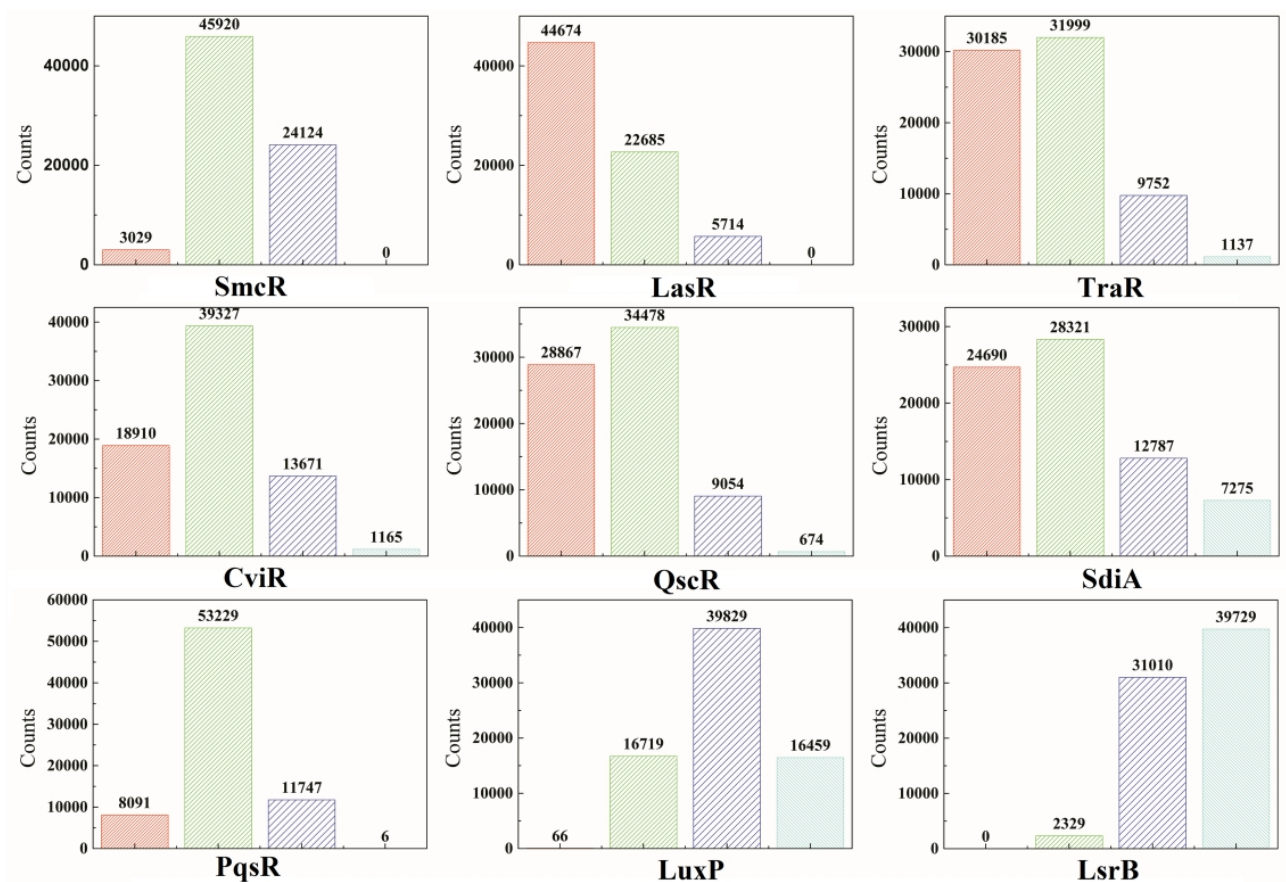

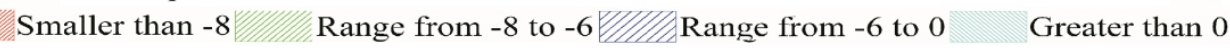

Fig. 5. FBEs distributions for the expanded ligands and nine QS receptors. 
Fig 6. Typical and the strongest binding FBEs results for the screened nine ligands and receptors. 


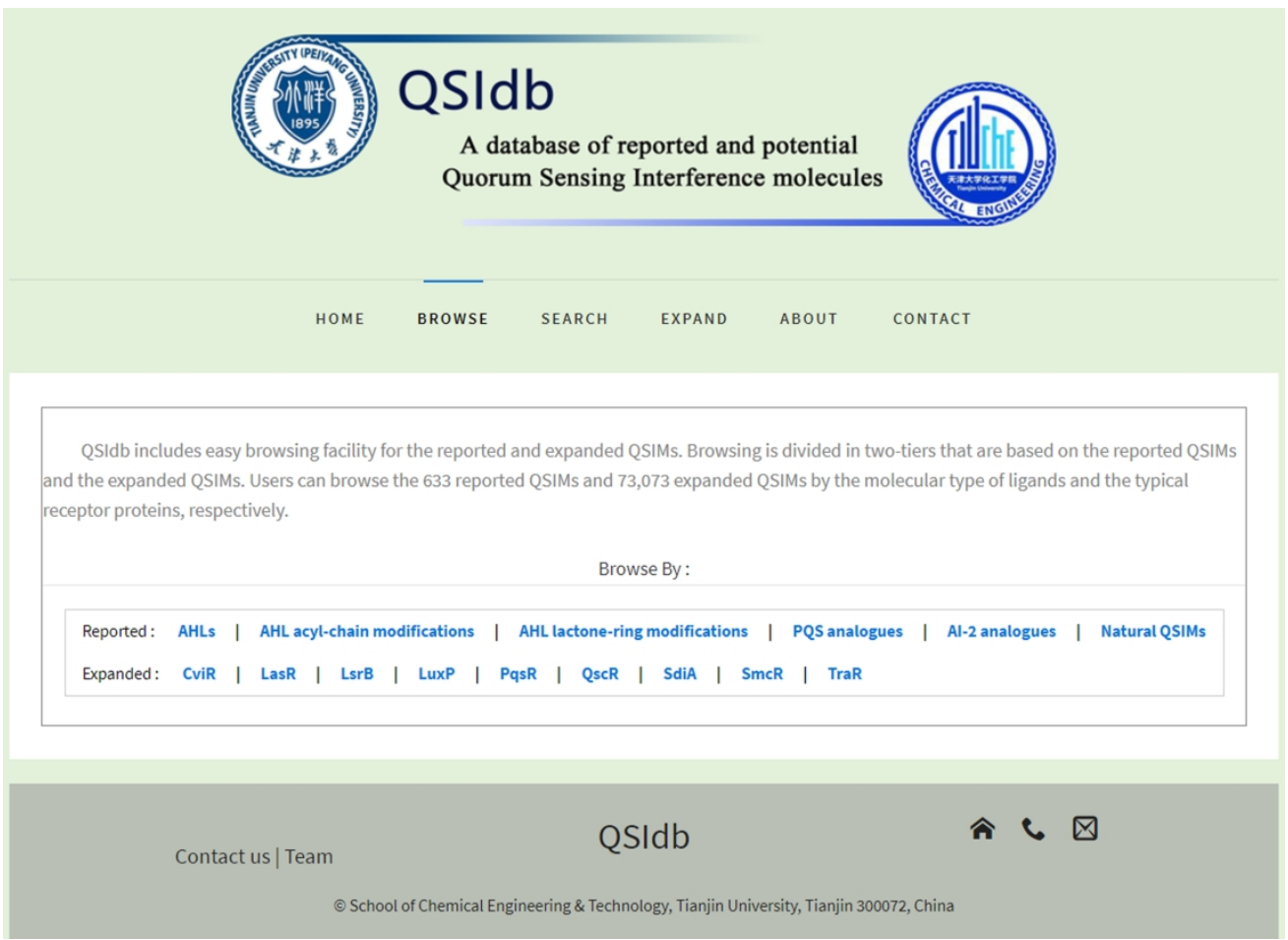

Fig 7. Browse facility for the reported and expanded QSIMs.

$139 \times 101 \mathrm{~mm}(600 \times 600 \mathrm{DPI})$ 
QSIdb includes "SEARCH" and "EXPAND" searching facilities for reported and expanded QSIMs, respectively. In this search option, query box is provided in which user can enter the query on the basis of PubChem ID and SMILES of ligands or the typical receptor proteins for the searching of about 73,073 expanded QSIMs.

\section{Expand By:}

- PubChem CID [e.g, 10130163]

SMILES [e.g, $\mathrm{C}=\mathrm{CCSCC}=\mathrm{C}$ ]

Receptor [e.g, cviR]

Go

\section{Reset}

Contact us | Team

QSIdb

ก 6 .

OSchool of Chemical Engineering \& Technology, Tianjin University, Tianjin 300072, China

Fig 8. "EXPAND" searching facility for the expanded QSIMs.

$139 \times 117 \mathrm{~mm}(600 \times 600 \mathrm{DPI})$ 


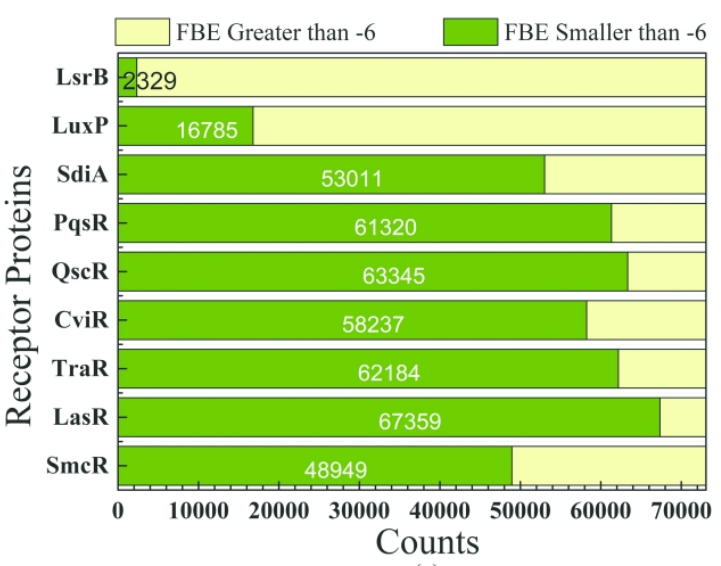

(a)

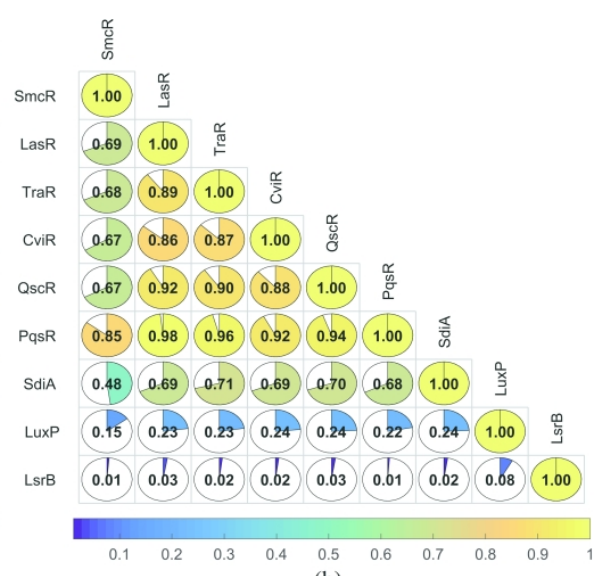

(b)

Fig 9. The analysis and discussion for the receptors binding pockets similarity. (a) Potential QSIs distribution for nine receptors; (b) Results of pocketeditx,y for various receptor pairwise.

\section{$178 \times 79 \mathrm{~mm}(600 \times 600 \mathrm{DPI})$}


Table 1. Fixed binding site for the nine typical receptors

\begin{tabular}{|c|c|l|c|}
\hline Receptors & PDB code & Hydrogen bonding & References \\
\hline LasR & 2UV0 & Tyr56, Trp60, Asp73, Ser129 & {$[1]$} \\
\hline TraR & 1L3L & Tyr53, Trp57, Asp70 & {$[2]$} \\
\hline CviR & 3QP1 & Tyr80, Trp84, Asp97, Ser155 & {$[3]$} \\
\hline QscR & 3SZT & Tyr58, Trp62, Asp75, Ser38 & {$[4]$} \\
\hline SdiA & 4Y15 & Tyr63, Trp67, Asp80, Ser43 & {$[5]$} \\
\hline SmcR & 3KZ9 & Asn133, Gln137 & {$[6]$} \\
\hline PqsR & 4JVD & Ile149, Ile168, Leu207, Ile236, Thr265 & {$[7]$} \\
\hline LuxP & 1JX6 & $\begin{array}{l}\text { Gln77, Ser79, Trp82, Asn159, Arg215, Thr266, } \\
\text { Asp267, Trp289, Arg310 }\end{array}$ & {$[8]$} \\
\hline LsrB & 1TJY & Lys35, Asp116, Asp166, Gln167, Ala222, Pro220 & {$[9]$} \\
\hline
\end{tabular}

\section{Reference}

1. Bottomley MJ, Muraglia E, Bazzo R et al. Molecular insights into quorum sensing in the human pathogen Pseudomonas aeruginosa from the structure of the virulence regulator Las $R$ bound to its autoinducer, Journal of Biological Chemistry 2007;282:13592-13600.

2. Zhang RG, Pappas KM, Brace JL et al. Structure of a bacterial quorum-sensing transcription factor complexed with pheromone and DNA, Nature 2002;417:971-974.

3. Chen G, Swem LR, Swem DL et al. A strategy for antagonizing quorum sensing, Molecular Cell 2011;42:199-209.

4. Lintz MJ, Oinuma K, Wysoczynski CL et al. Crystal structure of QscR, a Pseudomonas aeruginosa quorum sensing signal receptor, Proceedings of the National Academy of Sciences of the United States of America 2011;108:15763-15768.

5. Nguyen $\mathrm{Y}$, Nguyen NX, Rogers JL et al. Structural and mechanistic roles of novel chemical ligands on the SdiA quorum-sensing transcription regulator, mBio 2015;6:e02429-02414.

6. Rajamanikandan S, Jeyakanthan J, Srinivasan P. Binding mode exploration of LuxRthiazolidinedione analogues, e-pharmacophore-based virtual screening in the designing of LuxR inhibitors and its biological evaluation, Journal of Biomolecular Structure and Dynamics 2017;35:897-916.

7. Ilangovan $A$, Fletcher $M$, Rampioni $G$ et al. Structural basis for native agonist and synthetic inhibitor recognition by the Pseudomonas aeruginosa quorum sensing regulator PqsR (MvfR), PLoS Pathogens 2013;9:e1003508.

8. Chen $\mathrm{X}$, Schauder S, Potier $\mathrm{N}$ et al. Structural identification of a bacterial quorum-sensing signal containing boron, Nature 2002;415:545-549.

9. Miller, Stephen T, Xavier et al. Salmonella typhimurium Recognizes a Chemically Distinct Form of the Bacterial Quorum-Sensing Signal Al-2, Molecular Cell 2004;15:677-687. 
Table 2. The ligands regarded as both agonists and antagonists with specific concentrations

\begin{tabular}{|c|c|c|c|c|c|}
\hline Pub CID & Receptors & $\mathrm{IC}_{50}(\mu \mathrm{M})$ & Receptors & $\mathrm{EC}_{50}(\mu \mathrm{M})$ & SMILES \\
\hline 127293 & LasR, TraR & $0.11, *$ & PhzR & 0.011 & $\operatorname{CCCCCC}(=O) \operatorname{CC}(=\mathrm{O}) \mathrm{N}[\mathrm{C} @ \mathrm{H}] 1 \mathrm{CCOC} 1=\mathrm{O}$ \\
\hline 10221437 & LasR & 0.04 & PhzR, & 0.005 & $\operatorname{cccccccccccc}(=\mathrm{O}) \mathrm{N}[\mathrm{C} @ \mathrm{H}] 1 \mathrm{ccoc} 1=\mathrm{O}$ \\
\hline 25014956 & LuxR, TraR & $4.7,1.3$ & LasR & 3.4 & $\mathrm{C} 1 \mathrm{COC}(=\mathrm{O})[\mathrm{C} @ \mathrm{H}] 1 \mathrm{NC}(=\mathrm{O}) \mathrm{CC} 2=\mathrm{CC}=\mathrm{C}(\mathrm{C}=\mathrm{C} 2) \mathrm{SC}(\mathrm{F})(\mathrm{F}) \mathrm{F}$ \\
\hline 10131281 & LuxR, TraR,LasR & $0.4,0.25,1.05$ & PhzR & 0.006 & $\operatorname{cccccccccc}(=\mathrm{O}) \mathrm{N}[\mathrm{C} @ \mathrm{H}] 1 \mathrm{CcOC} 1=\mathrm{O}$ \\
\hline 15384158 & LuxR & 3.4 & LasR & $>10$ & $\mathrm{C} 1 \mathrm{COC}(=\mathrm{O})[\mathrm{C} @ \mathrm{H}] 1 \mathrm{NC}(=\mathrm{O}) \mathrm{CCC} 2=\mathrm{CC} 3=\mathrm{C}(\mathrm{C}=\mathrm{C} 2) \mathrm{OCO} 3$ \\
\hline 11536248 & TraR & 0.83 & LasR & 0.54 & $\mathrm{C} 1 \mathrm{COC}(=\mathrm{O})[\mathrm{C} @ \mathrm{H}] 1 \mathrm{NC}(=\mathrm{O}) \mathrm{CC}(=\mathrm{O}) \mathrm{CC} 2=\mathrm{CC}=\mathrm{CC}=\mathrm{C} 2$ \\
\hline 25014704 & LasR & 3.97 & LuxR & $>200$ & $\mathrm{C} 1 \mathrm{COC}(=\mathrm{O})[\mathrm{C} @ \mathrm{H}] 1 \mathrm{NC}(=\mathrm{O}) \mathrm{CC} 2=\mathrm{CC}(=\mathrm{CC}=\mathrm{C} 2) \mathrm{Cl}$ \\
\hline 25014624 & LasR & 4.06 & LuxR & $>50$ & $\mathrm{C} 1 \mathrm{COC}(=\mathrm{O})[\mathrm{C} @ \mathrm{H}] 1 \mathrm{NC}(=\mathrm{O}) \mathrm{CC} 2=\mathrm{CC}(=\mathrm{CC}=\mathrm{C} 2) \mathrm{Br}$ \\
\hline 25014709 & LasR & 0.61 & LuxR & 0.35 & $\mathrm{C} 1 \mathrm{COC}(=\mathrm{O})[\mathrm{C} @ \mathrm{H}] 1 \mathrm{NC}(=\mathrm{O}) \mathrm{CC} 2=\mathrm{CC}(=\mathrm{CC}=\mathrm{C} 2)[\mathrm{N}+](=\mathrm{O})[\mathrm{O}-]$ \\
\hline 24179365 & TraR, LasR & 0.464 .67 & LasR & 6.28 & $\mathrm{C} 1 \mathrm{COC}(=\mathrm{O})[\mathrm{C} @ \mathrm{H}] 1 \mathrm{NC}(=\mathrm{O}) \mathrm{COC} 2=\mathrm{CC}=\mathrm{C}(\mathrm{C}=\mathrm{C} 2) \mathrm{OC}(\mathrm{F})(\mathrm{F}) \mathrm{F}$ \\
\hline 10059709 & LuxR, TraR & $0.131,3.2$ & LasR & 0.13 & $\operatorname{CcCC}(=\mathrm{O}) \mathrm{CC}(=\mathrm{O}) \mathrm{N}[\mathrm{C} @ \mathrm{H}] 1 \mathrm{CCSC} 1=\mathrm{O}$ \\
\hline 10935915 & LuxR, TraR & $0.45,1.8$ & LasR & 0.007 & $\operatorname{cccccccccc}(=\mathrm{O}) \operatorname{cc}(=\mathrm{O}) \mathrm{N}[\mathrm{C} @ \mathrm{H}] 1 \mathrm{ccsc} 1=\mathrm{O}$ \\
\hline 53484106 & LuxR & 0.35 & TraR & 20 & $\operatorname{cccccc}(=0) \operatorname{Cc}(=0) N[C @ H] 1 \operatorname{ccsc} 1=0$ \\
\hline 57401661 & LuxP & 159.7 & LuxP & 19.5 & $\mathrm{C}[\mathrm{C} @ \mathrm{H}]([\mathrm{C} @ \mathrm{H}](\mathrm{C}(=\mathrm{O}) \mathrm{C}(=\mathrm{O}) \mathrm{C}) \mathrm{O}) \mathrm{O}$ \\
\hline 25023205 & LsrB & 5.04 & LuxP & 1.01 & $\operatorname{Ccccc}(=\mathrm{O}) \mathrm{C}(=\mathrm{O})[\mathrm{C} @ \mathrm{H}](\mathrm{CO}) \mathrm{O}$ \\
\hline 57403389 & LuxP & 169 & LuxP & 0.65 & $\mathrm{C}[\mathrm{C} @ @ \mathrm{H}]([\mathrm{C} @ \mathrm{H}](\mathrm{C}(=\mathrm{O}) \mathrm{C}(=\mathrm{O}) \mathrm{C}) \mathrm{O}) \mathrm{O}$ \\
\hline 25023206 & LsrB & 24.9 & LuxP & 1.52 & $\operatorname{ccccccc}(=\mathrm{O}) \mathrm{C}(=\mathrm{O})[\mathrm{C} @ \mathrm{H}](\mathrm{CO}) \mathrm{O}$ \\
\hline 25023204 & LsrB & 5.3 & LuxP & 0.75 & $\operatorname{CccC}(=\mathrm{O}) \mathrm{C}(=\mathrm{O})[\mathrm{C} @ \mathrm{H}](\mathrm{CO}) \mathrm{O}$ \\
\hline 57392938 & LuxP & 57.54 & LuxP & 6.21 & C[C@@H]([C@@H](C(=O)C(=O)C)O)O \\
\hline 25023203 & LsrB & 50 & LuxP & 0.58 & $\mathrm{CCC}(=\mathrm{O}) \mathrm{C}(=\mathrm{O})[\mathrm{C} @ \mathrm{H}](\mathrm{CO}) \mathrm{O}$ \\
\hline 45267703 & LsrB & 5 & LuxP & 1.35 & $\operatorname{cccccc}(=\mathrm{O}) \mathrm{C}(=\mathrm{O})[\mathrm{C} @ \mathrm{H}](\mathrm{CO}) \mathrm{O}$ \\
\hline
\end{tabular}


Table 3. The potential broad-spectrum QSIs for the nine QS receptors

\begin{tabular}{|c|c|c|c|c|c|c|c|c|c|c|}
\hline CID & SMILES & SmcR & LasR & TraR & CviR & QscR & PqsR & SdiA & LuxP & LsrB \\
\hline 328 & $\mathrm{C} 1=\mathrm{CC}(=\mathrm{CC}=\mathrm{C} 1 \mathrm{C}(\mathrm{C}(=\mathrm{O}) \mathrm{O}) \mathrm{O}) \mathrm{O}$ & -6.1 & -7.9 & -6.5 & -7.2 & -6.8 & -6.1 & -7.1 & -7.2 & -6 \\
\hline 7532 & $C 1=C C=C(C=C 1) C S(=O)(=0) O$ & -6.2 & -7.9 & -7.1 & -7.2 & -6.6 & -6.3 & -7.4 & -7.3 & -6.8 \\
\hline 10313 & $\mathrm{C} 1=\mathrm{CC}=\mathrm{C}(\mathrm{C}=\mathrm{C} 1) \mathrm{C}(=\mathrm{O}) \mathrm{NO}$ & -6.5 & -7.8 & -7.3 & -7.4 & -7.5 & -6.4 & -7.4 & -6.2 & -7 \\
\hline 11955 & $C 1=C C=C(C=C 1) C(=O) N N$ & -6.6 & -7.7 & -7.4 & -7.5 & -7.5 & -6.4 & -7.3 & -6.1 & -6.9 \\
\hline 65723 & $C 1=C C=C(C=C 1) S(=O)(=O) N N$ & -6.1 & -7.5 & -7 & -7.2 & -7.5 & -6.6 & -7.3 & -7.3 & -6.7 \\
\hline 69033 & $\mathrm{C} 1=\mathrm{CC}=\mathrm{C}(\mathrm{C}=\mathrm{C} 1) \mathrm{S}(=\mathrm{O})(=\mathrm{O}) \mathrm{NO}$ & -6.1 & -7.5 & -7 & -7.3 & -7.5 & -6.6 & -7.3 & -7.5 & -6.7 \\
\hline 74128 & $\mathrm{C} 1=\mathrm{CC}=\mathrm{C} 2 \mathrm{C}=\mathrm{C}(\mathrm{C}=\mathrm{CC} 2=\mathrm{C} 1) \mathrm{CO}$ & -6.6 & -7.9 & -8.2 & -8 & -7.7 & -7.1 & -8.6 & -6 & -6.4 \\
\hline 77864 & $C C(C) C C 1=C C(=O) C=C C 1=0$ & -7.2 & -7.8 & -7.3 & -7.3 & -7 & -6.2 & -7.8 & -6.6 & -6.2 \\
\hline 78391 & $C 1=C C=C(C=C 1) C(O) S(=O)(=0) O$ & -6.4 & -7.5 & -6.7 & -7 & -7.1 & -6.2 & -7.4 & -7.4 & -6.3 \\
\hline 85782 & $C 1=C C(=C(C=C 1 C(C(=0) O) O) O) O$ & -6 & -7.7 & -6.5 & -6.5 & -6.9 & -6 & -7.3 & -6.9 & -6.4 \\
\hline
\end{tabular}

Unit of the free binding energy, $\mathrm{kCal} / \mathrm{mol}$ 


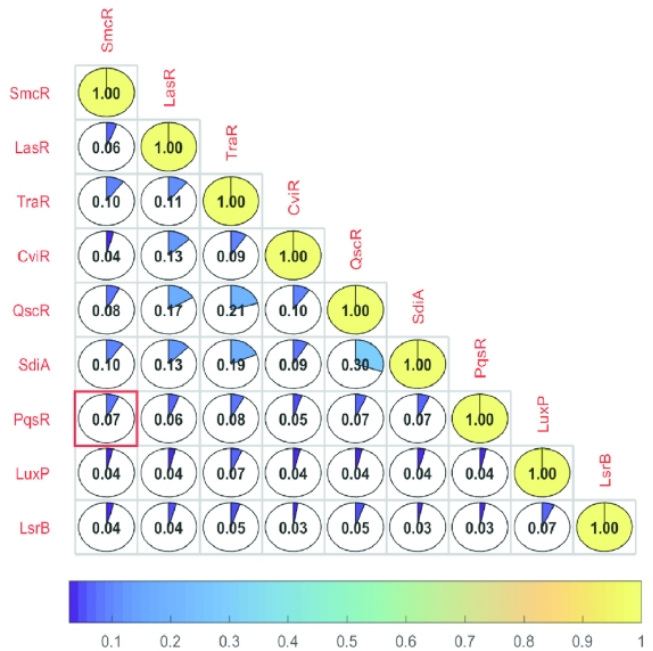

(a)

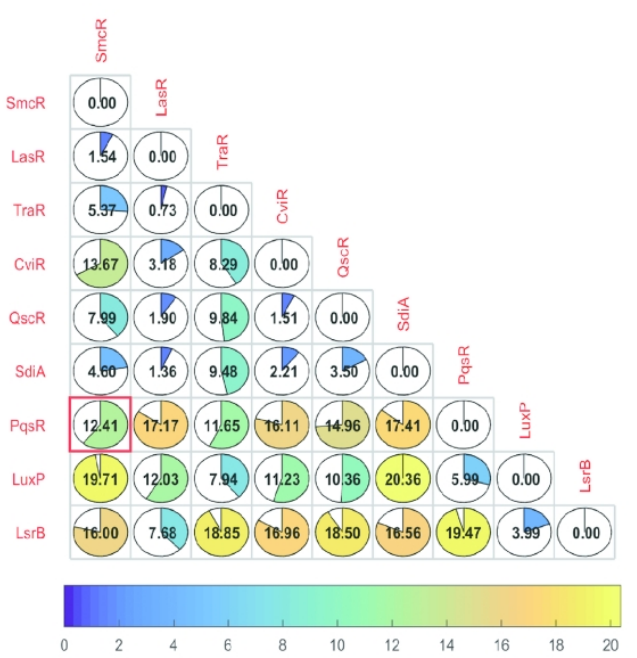

(b)

Fig S1. The analysis and discussion for QS receptors similarity of amino acids sequence and threedimensional structure. (a) Similarity analysis of amino acids sequence of nine receptors; (b) Similarity analysis of the three-dimensional structure of nine receptors. 


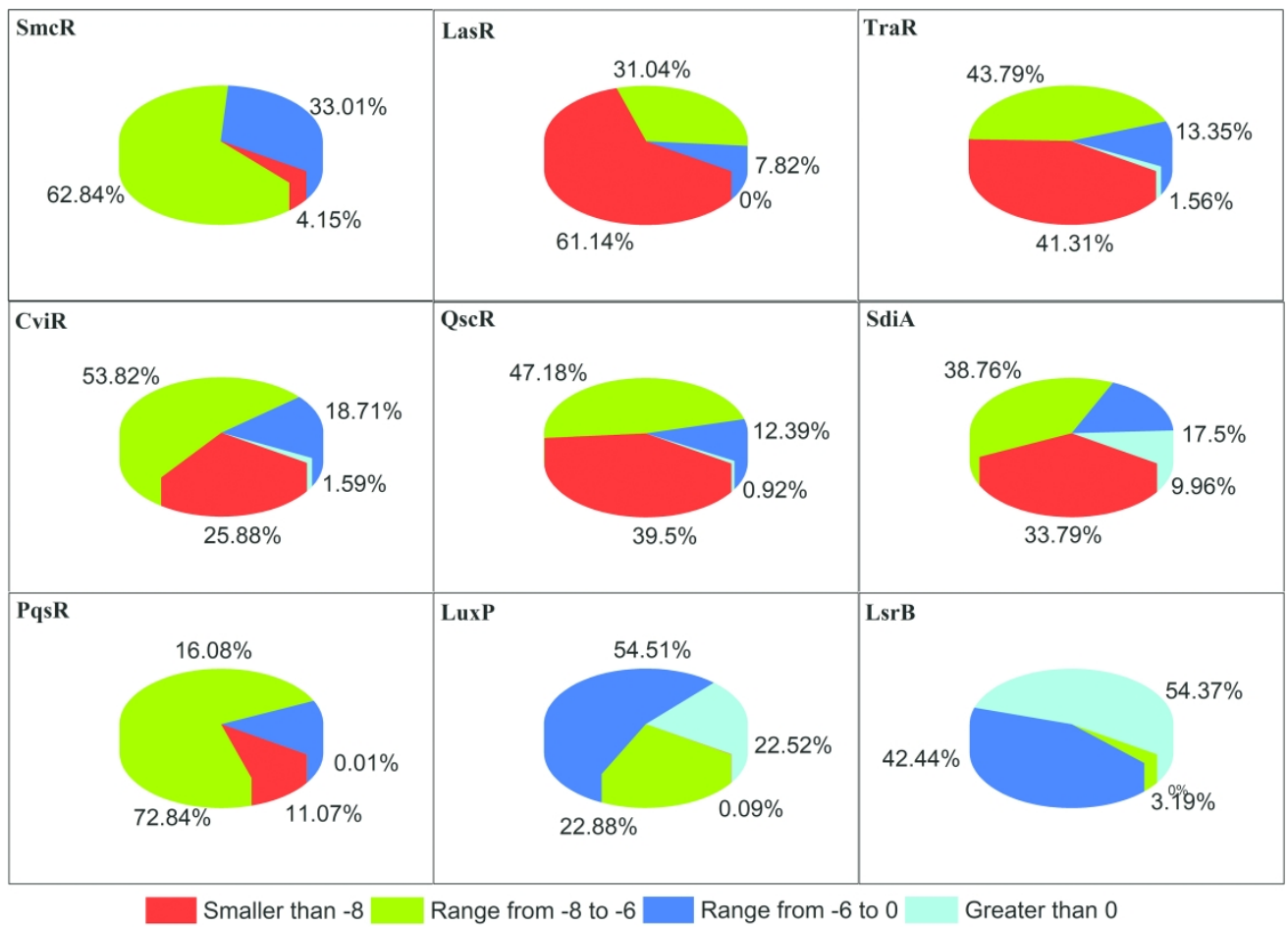

Fig. S2. Piecharts for FBEs distributions for the expanded ligands and nine QS receptors. $178 \times 129 \mathrm{~mm}(600 \times 600 \mathrm{DPI})$ 


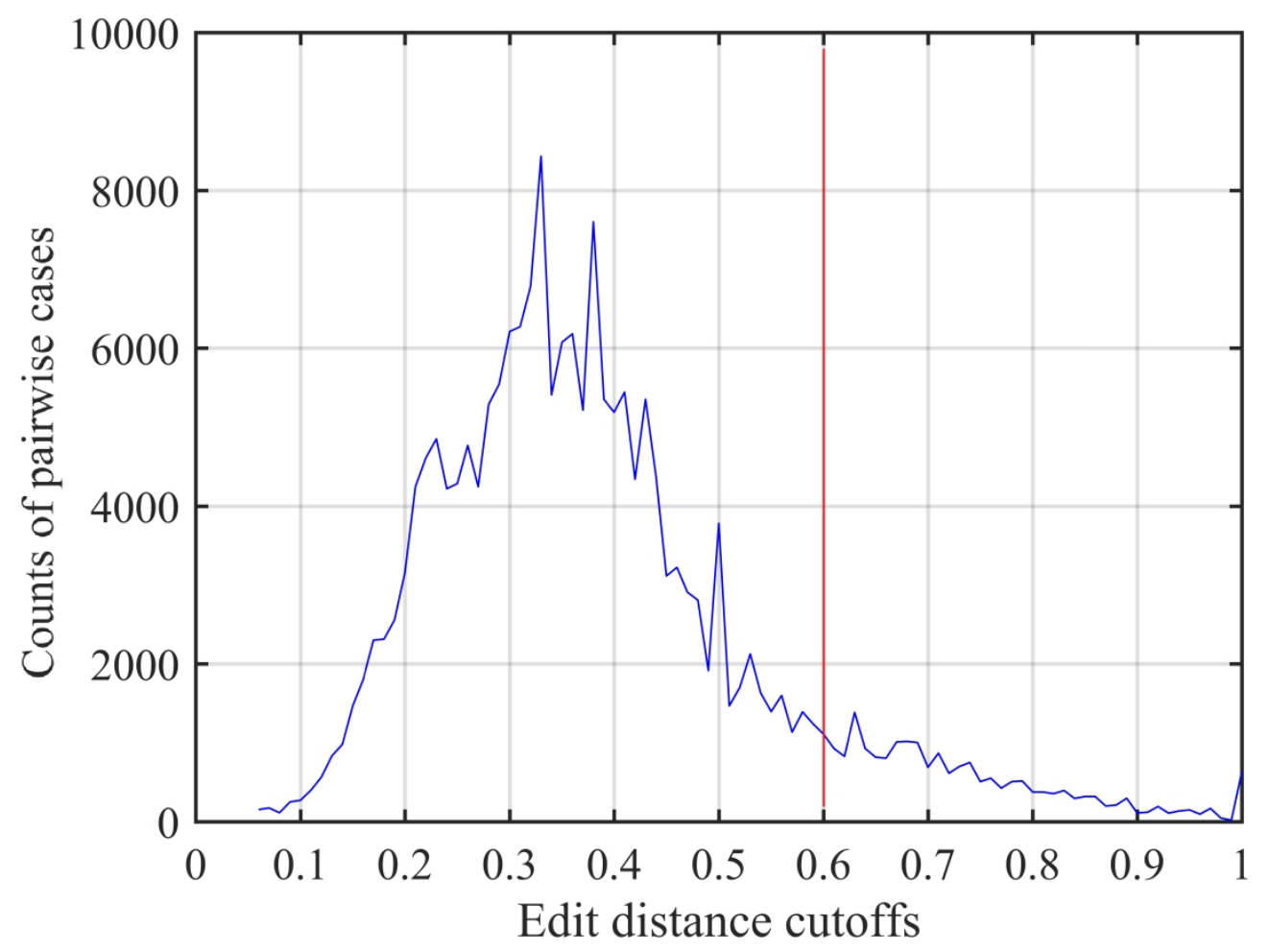

Fig. S3. The distribution of similarities for different distance cutoffs.

$999 \times 749 \mathrm{~mm}(120 \times 120 \mathrm{DPI})$ 
Table S1. The total potential broad-spectrum QSIs screened on the nine QS receptors

\begin{tabular}{|c|c|c|c|c|c|c|c|c|c|c|}
\hline PubChem CID & SMILES & SmcR & LasR & TraR & CviR & QscR & PqsR & SdiA & LuxP & LsrB \\
\hline 328 & $\mathrm{C} 1=\mathrm{CC}(=\mathrm{CC}=\mathrm{C} 1 \mathrm{C}(\mathrm{C}(=\mathrm{O}) \mathrm{O}) \mathrm{O}) \mathrm{O}$ & -6.1 & -7.9 & -6.5 & -7.2 & -6.8 & -6.1 & -7.1 & -7.2 & -6 \\
\hline 7532 & $C 1=C C=C(C=C 1) C S(=0)(=0) O$ & -6.2 & -7.9 & -7.1 & -7.2 & -6.6 & -6.3 & -7.4 & -7.3 & -6.8 \\
\hline 10313 & $\mathrm{C} 1=\mathrm{CC}=\mathrm{C}(\mathrm{C}=\mathrm{C} 1) \mathrm{C}(=\mathrm{O}) \mathrm{NO}$ & -6.5 & -7.8 & -7.3 & -7.4 & -7.5 & -6.4 & -7.4 & -6.2 & -7 \\
\hline 11955 & $C 1=C C=C(C=C 1) C(=O) N N$ & -6.6 & -7.7 & -7.4 & -7.5 & -7.5 & -6.4 & -7.3 & -6.1 & -6.9 \\
\hline 65723 & $C 1=C C=C(C=C 1) S(=O)(=O) N N$ & -6.1 & -7.5 & -7 & -7.2 & -7.5 & -6.6 & -7.3 & -7.3 & -6.7 \\
\hline 69033 & $\mathrm{C} 1=\mathrm{CC}=\mathrm{C}(\mathrm{C}=\mathrm{C} 1) \mathrm{S}(=\mathrm{O})(=\mathrm{O}) \mathrm{NO}$ & -6.1 & -7.5 & -7 & -7.3 & -7.5 & -6.6 & -7.3 & -7.5 & -6.7 \\
\hline 74128 & $\mathrm{C} 1=\mathrm{CC}=\mathrm{C} 2 \mathrm{C}=\mathrm{C}(\mathrm{C}=\mathrm{CC} 2=\mathrm{C} 1) \mathrm{CO}$ & -6.6 & -7.9 & -8.2 & -8 & -7.7 & -7.1 & -8.6 & -6 & -6.4 \\
\hline 77864 & $C C(C) C C 1=C C(=O) C=C C 1=0$ & -7.2 & -7.8 & -7.3 & -7.3 & -7 & -6.2 & -7.8 & -6.6 & -6.2 \\
\hline 78391 & $C 1=C C=C(C=C 1) C(O) S(=O)(=0) O$ & -6.4 & -7.5 & -6.7 & -7 & -7.1 & -6.2 & -7.4 & -7.4 & -6.3 \\
\hline 85782 & $\mathrm{C} 1=\mathrm{CC}(=\mathrm{C}(\mathrm{C}=\mathrm{C} 1 \mathrm{C}(\mathrm{C}(=\mathrm{O}) \mathrm{O}) \mathrm{O}) \mathrm{O}) \mathrm{O}$ & -6 & -7.7 & -6.5 & -6.5 & -6.9 & -6 & -7.3 & -6.9 & -6.4 \\
\hline 96574 & $\operatorname{ccoc}(=0) \operatorname{cc} 1=C C=C C(=C 1) C$ & -6.6 & -7.3 & -7.8 & -7.6 & -7.4 & -6.1 & -8.3 & -7 & -6 \\
\hline 98068 & $\mathrm{C} 1=\mathrm{CC}(=\mathrm{CC}=\mathrm{C} 1 \mathrm{C}(\mathrm{C}(=\mathrm{O}) \mathrm{O}) \mathrm{O}) \mathrm{F}$ & -6.4 & -7.8 & -7 & -7.5 & -7.4 & -6.3 & -7.7 & -7.2 & -6.3 \\
\hline 137282 & $\mathrm{C} 1=\mathrm{CC}=\mathrm{C} 2 \mathrm{C}=\mathrm{C}(\mathrm{C}=\mathrm{CC} 2=\mathrm{C} 1) \mathrm{CN}$ & -6.6 & -8 & -8.3 & -8 & -7.7 & -7.1 & -8.6 & -6 & -6.2 \\
\hline 138430 & $\mathrm{C} 1 \mathrm{CC} 2 \mathrm{C} 3=\mathrm{CC}=\mathrm{CC}=\mathrm{C} 3 \mathrm{C} 1 \mathrm{~N} 2$ & -6.7 & -7.3 & -7.4 & -7.7 & -7.3 & -6.5 & -8 & -6 & -6.3 \\
\hline 139951 & $\mathrm{C} 1 \mathrm{C} 2 \mathrm{C} 1 \mathrm{C} 3 \mathrm{CC} 2 \mathrm{C} 4=\mathrm{CC}=\mathrm{CC}=\mathrm{C} 34$ & -7.2 & -8.4 & -8.1 & -8 & -7.7 & -7.1 & -7.9 & -6 & -7.1 \\
\hline 141510 & $\mathrm{C}=\mathrm{C} 1 \mathrm{CC} 1 \mathrm{C} 2=\mathrm{CC}=\mathrm{CC}=\mathrm{C} 2$ & -7.2 & -7.3 & -7.9 & -7.6 & -6.9 & -6 & -7.9 & -6.2 & -6.4 \\
\hline 144215 & $\mathrm{C} 1 \mathrm{CC} 2 \mathrm{C} 1 \mathrm{C} 3 \mathrm{CC} 2 \mathrm{C} 4=\mathrm{CC}=\mathrm{CC}=\mathrm{C} 34$ & -7.1 & -9.1 & -8.5 & -8.2 & -8.2 & -7.3 & -8.3 & -6.1 & -6.6 \\
\hline 185912 & $\mathrm{C} 1=\mathrm{CC}=\mathrm{C} 2 \mathrm{C}(\mathrm{C}=\mathrm{CC} 2=\mathrm{C} 1) \mathrm{C}(=\mathrm{O}) \mathrm{O}$ & -6.5 & -7.6 & -7.4 & -7.8 & -7.5 & -6.6 & -8.3 & -6.5 & -7 \\
\hline 193409 & $\mathrm{C} 1=\mathrm{CC}=\mathrm{C} 2 \mathrm{C}=\mathrm{C}(\mathrm{C}=\mathrm{C} C 2=\mathrm{C} 1) \mathrm{C}(=\mathrm{N}) \mathrm{N}$ & -7.3 & -8.9 & -8.9 & -8.6 & -8.3 & -7.7 & -9.2 & -6.9 & -6 \\
\hline 287162 & $\mathrm{C} 1 \mathrm{CC} 2 \mathrm{CC} 1 \mathrm{C} 3 \mathrm{C} 2 \mathrm{C} 4=\mathrm{CC}=\mathrm{CC}=\mathrm{C} 34$ & -6.8 & -9.1 & -8.6 & -8.3 & -8.4 & -7.2 & -8.9 & -6.3 & -6.3 \\
\hline 287421 & $\mathrm{CC} 1 \mathrm{CC} 1 \mathrm{CC} 2=\mathrm{CC}=\mathrm{CC}=\mathrm{C} 2$ & -7.2 & -7.7 & -8.1 & -8.1 & -7.3 & -6.4 & -7.8 & -6.2 & -6.3 \\
\hline 302932 & $\mathrm{C} 1=\mathrm{CC}(=\mathrm{C}(\mathrm{C}(=\mathrm{C} 1 \mathrm{C}(=\mathrm{O}) \mathrm{O}) \mathrm{F}) \mathrm{F}) \mathrm{F}$ & -6.5 & -7.9 & -7.4 & -7.4 & -7.8 & -6.3 & -7.5 & -6.4 & -6.1 \\
\hline 317708 & $\mathrm{C} 1 \mathrm{CC} 1 \mathrm{C} 2 \mathrm{CCC} 3=\mathrm{CC}=\mathrm{CC}=\mathrm{C} 23$ & -6.4 & -8.1 & -8.2 & -8.1 & -7.4 & -6.7 & -8.4 & -6.5 & -6.9 \\
\hline
\end{tabular}




\begin{tabular}{|c|c|c|c|c|c|c|c|c|c|c|}
\hline 430144 & $\mathrm{C} 1=\mathrm{CC}=\mathrm{C}(\mathrm{C}=\mathrm{C} 1) \mathrm{N}(\mathrm{O}) \mathrm{S}(=\mathrm{O})(=0) \mathrm{O}$ & -6.2 & -7.7 & -6.7 & -7.3 & -7.2 & -6.4 & -7.6 & -7.5 & -6.6 \\
\hline 431079 & $C 1=C C=C(C=C 1) N S(=0)(=0) O$ & -6.1 & -7.9 & -7 & -7 & -6.9 & -6.3 & -7.1 & -7.1 & -6.1 \\
\hline 439435 & $C 1=C C(=C(C=C 1 C C(C(=0) O) O) O) O$ & -6.6 & -8.1 & -7.2 & -6.7 & -7.2 & -6.5 & -7.4 & -6.8 & -6.4 \\
\hline 521908 & $\mathrm{C} 1=\mathrm{CC}=\mathrm{C}(\mathrm{C}=\mathrm{C} 1) \mathrm{S}(=\mathrm{NO})(=\mathrm{O}) \mathrm{O}$ & -6 & -7.5 & -7.2 & -7.3 & -7.5 & -6.4 & -7.3 & -6.5 & -6.6 \\
\hline 562002 & $C 1 C C 1 C C C 2=C C=C C=C 2$ & -7 & -7.8 & -7.8 & -7.7 & -6.8 & -6.1 & -7.6 & -6.2 & -6 \\
\hline 565120 & $\mathrm{C}=\mathrm{C}=\mathrm{CCOC} 1=\mathrm{CC}=\mathrm{CC}=\mathrm{C} 1$ & -6.5 & -7.6 & -7.4 & -7.5 & -7.1 & -6 & -7.4 & -6 & -6.1 \\
\hline 588433 & $\mathrm{C} 1 \mathrm{CC} 2 \mathrm{CC} 1 \mathrm{C}=\mathrm{C} 2 \mathrm{C} 3=\mathrm{CC}=\mathrm{CC}=\mathrm{C} 3$ & -8.3 & -8.6 & -9.1 & -9.5 & -8.2 & -7.5 & -8.9 & -6.7 & -6.5 \\
\hline 602809 & $\mathrm{C} 1 \mathrm{C}=\mathrm{CC} 2 \mathrm{CC} 1 \mathrm{C}=\mathrm{C} 2 \mathrm{C} 3=\mathrm{CC}=\mathrm{CC}=\mathrm{C} 3$ & -8.2 & -9.1 & -9.1 & -9.6 & -8.4 & -8 & -9 & -6.4 & -6.2 \\
\hline 1512675 & $\operatorname{coc}(=0) \operatorname{CcC} 1=C C(=C C=C 1) O$ & -6.5 & -7.8 & -7.6 & -6.9 & -7.3 & -6.2 & -7.6 & -6.3 & -6.5 \\
\hline 4615423 & $\mathrm{CC} 1=\mathrm{CC}=\mathrm{C}(\mathrm{C}=\mathrm{C} 1) \mathrm{OS}(=\mathrm{O})(=\mathrm{O}) \mathrm{O}$ & -6.6 & -7.4 & -7.4 & -7.3 & -7.2 & -6.7 & -8 & -7.4 & -6 \\
\hline 5070076 & $C C C 1 C C 2=C C=C C=C 2 C 1=O$ & -6.1 & -8.4 & -8.2 & -8.2 & -8.2 & -6.7 & -8.5 & -6 & -6.4 \\
\hline 6421254 & $\mathrm{C} 1 \mathrm{CC} 2 \mathrm{CC} 3=\mathrm{CC}=\mathrm{CC}=\mathrm{C} 3 \mathrm{C} 2 \mathrm{C} 1$ & -6.3 & -8.4 & -8 & -8.2 & -7 & -7.2 & -8.3 & -6.1 & -7.3 \\
\hline 7567094 & $C 1=C C=C(C=C 1) C(=O) C 2 C=C C=C 2$ & -8 & -9 & -8.8 & -9.1 & -8.1 & -7.1 & -8.5 & -6.8 & -6.9 \\
\hline 9815760 & $\mathrm{C} 1=\mathrm{CC}(=\mathrm{C}(\mathrm{C}=\mathrm{C} 1 \mathrm{C}(\mathrm{C}(\mathrm{C}(=\mathrm{O}) \mathrm{O}) \mathrm{O}) \mathrm{O}) \mathrm{O}) \mathrm{O}$ & -6 & -7.8 & -7.2 & -6.7 & -7.3 & -6.8 & -7.4 & -7.4 & -6.7 \\
\hline 10035212 & $\operatorname{ccccc}(C 1=\operatorname{cc}(=C C=C 1) O) O$ & -6.8 & -7.9 & -7.7 & -7.1 & -7.4 & -6.2 & -7.7 & -6.3 & -6 \\
\hline 10192593 & $\mathrm{CCCCC} 1=\mathrm{C}(\mathrm{C}(=\mathrm{CC}=\mathrm{C} 1) \mathrm{O}) \mathrm{O}$ & -6.7 & -7.5 & -6.8 & -6.8 & -7.4 & -6 & -7.2 & -6.3 & -6.4 \\
\hline 10855821 & $C C(=C) C C 1=C(C(=C C=C 1) O) O$ & -6.8 & -7.3 & -6.9 & -6.9 & -7.4 & -6.2 & -7.1 & -6 & -6.8 \\
\hline 10931557 & $\mathrm{C} 1 \mathrm{CC} 1=\mathrm{CCC} 2=\mathrm{CC}=\mathrm{CC}=\mathrm{C} 2$ & -7.3 & -8.2 & -8.3 & -8.1 & -7.5 & -6.3 & -8.2 & -6.4 & -6.4 \\
\hline 10931558 & $\mathrm{C} 1 \mathrm{C}=\mathrm{CCC} 1 \mathrm{C} 2=\mathrm{CC}=\mathrm{CC}=\mathrm{C} 2$ & -7.8 & -8 & -8.2 & -8.3 & -7.6 & -6.7 & -8.1 & -6.5 & -6.3 \\
\hline 10931712 & $\mathrm{C}=\mathrm{C} 1 \mathrm{CC} 1 \mathrm{CCC} 2=\mathrm{CC}=\mathrm{CC}=\mathrm{C} 2$ & -7.3 & -8.1 & -8.4 & -8.2 & -7.7 & -6.6 & -8.4 & -6.7 & -6.4 \\
\hline 11051794 & $\mathrm{C} 1 \mathrm{C} 2 \mathrm{CC} 1 \mathrm{C} 2 \mathrm{C} 3=\mathrm{CC}=\mathrm{CC}=\mathrm{C} 3$ & -6.8 & -7.5 & -7.5 & -7.8 & -7.2 & -6.2 & -7.9 & -6.2 & -6 \\
\hline 11084048 & $\mathrm{C} 1 \mathrm{CC} 2=\mathrm{CC}=\mathrm{CC}=\mathrm{C} 2 \mathrm{C} 1 \mathrm{OO}$ & -6.2 & -7.7 & -7.1 & -7.3 & -7.5 & -6.5 & -7.7 & -6.6 & -7 \\
\hline 11332716 & $\mathrm{C} 1 \mathrm{C}=\mathrm{CCC} 2 \mathrm{C} 1 \mathrm{CC} 3=\mathrm{CC}=\mathrm{CC}=\mathrm{C} 23$ & -6.1 & -9 & -8 & -7.6 & -7.5 & -7.3 & -8.6 & -6 & -6.1 \\
\hline 11469142 & $\mathrm{C}=\mathrm{C} 1 \mathrm{CCC} 2=\mathrm{CC}=\mathrm{CC}=\mathrm{C} 2 \mathrm{O} 1$ & -6 & -7.9 & -8 & -7.7 & -7 & -6.6 & -8.2 & -6 & -6.3 \\
\hline 11735538 & $\operatorname{ccoc}(=0) \operatorname{Cc} 1=C C(=C C=C 1) F$ & -6.6 & -7.7 & -7.9 & -7.4 & -7.1 & -6 & -7.8 & -6.7 & -6.3 \\
\hline 11816356 & $\mathrm{C} 1=\mathrm{CC}=\mathrm{C}(\mathrm{C}=\mathrm{C} 1) \mathrm{S}(=\mathrm{O})(=\mathrm{O}) \mathrm{C}(\mathrm{F}) \mathrm{F}$ & -6.5 & -7.4 & -7.1 & -7.5 & -7.3 & -6 & -7.7 & -6.3 & -6 \\
\hline
\end{tabular}




\begin{tabular}{|c|c|c|c|c|c|c|c|c|c|c|}
\hline 12031685 & $C 1 C=C C C 1 C C 2=C C=C C=C 2$ & -7.9 & -8.5 & -8.5 & -8.6 & -7.8 & -6.5 & -8.3 & -6.4 & -6.6 \\
\hline 12040849 & $\operatorname{coc}(=0) \operatorname{CcC} 1=\operatorname{CC}(=C C=C 1) F$ & -6.6 & -8 & -8 & -7.2 & -7.2 & -6.2 & -7.9 & -6.6 & -6.6 \\
\hline 12084350 & $\mathrm{C} 1=\mathrm{CC}=\mathrm{C}(\mathrm{C}=\mathrm{C} 1) \mathrm{S}(=\mathrm{O})(=\mathrm{O}) \mathrm{N}=\mathrm{N}$ & -6.1 & -7.6 & -7.2 & -7 & -7.4 & -6.6 & -7.5 & -7.3 & -6.5 \\
\hline 12249731 & $\mathrm{C} 1 \mathrm{C}=\mathrm{CCC} 1 \mathrm{C} 2=\mathrm{C}(\mathrm{C}(=\mathrm{CC}=\mathrm{C} 2) \mathrm{O}) \mathrm{O}$ & -7.5 & -8.5 & -7.9 & -8.1 & -8.3 & -6.5 & -8.2 & -6.8 & -6 \\
\hline 12326507 & $\mathrm{C}([\mathrm{C} @ @ \mathrm{H}](\mathrm{C}(=\mathrm{O}) \mathrm{O}) \mathrm{NC}(=\mathrm{O}) \mathrm{C}(\mathrm{F})(\mathrm{F}) \mathrm{F}) \mathrm{C}(=\mathrm{O}) \mathrm{O}$ & -6.3 & -6.6 & -7 & -6.3 & -7.1 & -6.5 & -7 & -6.9 & -6.4 \\
\hline 12383287 & $\mathrm{CC} 1 \mathrm{CC} 2 \mathrm{CC}(=\mathrm{O}) \mathrm{OC} 2 \mathrm{C} 1$ & -6.2 & -6.6 & -6.3 & -6 & -6.8 & -6.1 & -7.2 & -6.6 & -7.1 \\
\hline 12463222 & $\mathrm{C} 1=\mathrm{CC}=\mathrm{C}(\mathrm{C}=\mathrm{C} 1) \mathrm{S}(=\mathrm{O})(=\mathrm{O}) \mathrm{ONN}$ & -6.5 & -7.4 & -7.3 & -6.8 & -7.3 & -6.7 & -7.8 & -7.3 & -7.2 \\
\hline 12506472 & $\mathrm{CC} 1=\mathrm{CC}=\mathrm{C}(\mathrm{C}=\mathrm{C} 1) \mathrm{C}(=\mathrm{O}) \mathrm{CC}(\mathrm{C}) \mathrm{C}$ & -7.4 & -8.6 & -8.2 & -8.6 & -8 & -7 & -8.5 & -6.7 & -6.2 \\
\hline 12600454 & $\mathrm{CC} 1 \mathrm{CCCC} 1 \mathrm{C} 2=\mathrm{CC}=\mathrm{CC}=\mathrm{C} 2$ & -7.6 & -7.8 & -7.9 & -8.1 & -7.7 & -6.7 & -8.5 & -6.6 & -6.3 \\
\hline 12662762 & $\mathrm{C} 1=\mathrm{CC}=\mathrm{C}(\mathrm{C}=\mathrm{C} 1) \mathrm{C}(=\mathrm{O}) \mathrm{OC} 2 \mathrm{C}=\mathrm{CC}=\mathrm{C} 2$ & -7.1 & -9.5 & -8.9 & -9.3 & -8.5 & -6.8 & -9 & -6.8 & -6.5 \\
\hline 12662766 & $\mathrm{CC} 1=\mathrm{CC}=\mathrm{C}(\mathrm{C}=\mathrm{C} 1) \mathrm{C}(=\mathrm{O}) \mathrm{OC} 2 \mathrm{C}=\mathrm{CC}=\mathrm{C} 2$ & -6.4 & -10.2 & -9.2 & -9.8 & -9 & -7.4 & -9.5 & -6.6 & -6 \\
\hline 12665209 & $\mathrm{CC} 1 \mathrm{C} 2 \mathrm{C} 1 \mathrm{C} 3=\mathrm{CC}=\mathrm{CC}=\mathrm{C} 3 \mathrm{C} 2$ & -7.4 & -7.6 & -8.1 & -8.3 & -7.7 & -6.8 & -8.7 & -6.1 & -6.1 \\
\hline 12733519 & $\operatorname{cccccc}(\operatorname{C1C}=\operatorname{Cc}(=0) 01) 0$ & -6.7 & -7.4 & -7.1 & -7.3 & -7.1 & -6.1 & -7.2 & -6.8 & -6 \\
\hline 12810281 & $\mathrm{C} 1 \mathrm{C} 2 \mathrm{CC} 3 \mathrm{C} 1 \mathrm{C} 2 \mathrm{C} 4=\mathrm{CC}=\mathrm{CC}=\mathrm{C} 34$ & -7.5 & -8.5 & -8.2 & -8.3 & -7.8 & -7.1 & -8.1 & -6.6 & -6.4 \\
\hline 12827258 & $\mathrm{C} 1=\mathrm{CC}=\mathrm{C} 2 \mathrm{C}(=\mathrm{C} 1) \mathrm{C} 3=\mathrm{C}(\mathrm{O} 2) \mathrm{C}=\mathrm{CN} 3$ & -6.4 & -8.5 & -8 & -8 & -7.5 & -6.7 & -8.3 & -6.1 & -6.4 \\
\hline 12836317 & $\mathrm{C} 1 \mathrm{CC} 12 \mathrm{CC} 2 \mathrm{C} 3=\mathrm{CC}=\mathrm{CC}=\mathrm{C} 3$ & -7.4 & -7.7 & -7.9 & -8 & -7.4 & -6.5 & -8.1 & -6 & -6.1 \\
\hline 12864396 & $C C 1=C C 2 C C 1 C 3=C C=C C=C 23$ & -7 & -8.4 & -7.8 & -7.5 & -7.2 & -7 & -7.7 & -6.1 & -7.1 \\
\hline 12939347 & $\mathrm{CC} 1=\mathrm{CCC} 2 \mathrm{C} 1 \mathrm{CC}=\mathrm{CC} 2$ & -6.4 & -7.1 & -6.8 & -7 & -7.1 & -6 & -7.3 & -6 & -6.5 \\
\hline 13092026 & $\mathrm{C} 1=\mathrm{CC}=\mathrm{C}(\mathrm{C}(=\mathrm{C} 1) \mathrm{C} 2 \mathrm{C}(=\mathrm{O}) \mathrm{NC}(=\mathrm{O}) \mathrm{O} 2) \mathrm{N}$ & -6.7 & -8.8 & -7.7 & -7.6 & -7.4 & -6.8 & -8.6 & -6.2 & -7.6 \\
\hline 13197606 & $\mathrm{C}=\mathrm{CCC} \operatorname{coc} 1=\mathrm{CC}=\mathrm{CC}=\mathrm{C} 1 \mathrm{O}$ & -6.1 & -7.8 & -7.2 & -7.4 & -7.2 & -6 & -7.6 & -6.5 & -6.2 \\
\hline 13253247 & $\mathrm{C} 1 \mathrm{CC} 2 \mathrm{C} 1 \mathrm{CC} 3=\mathrm{CC}=\mathrm{CC}=\mathrm{C} 23$ & -6 & -7.8 & -7.6 & -8 & -7.1 & -6.7 & -8.2 & -6.1 & -7.3 \\
\hline 13495438 & $\mathrm{C} 1 \mathrm{C} 2 \mathrm{CC} 2 \mathrm{C} 1 \mathrm{CC} 3=\mathrm{CC}=\mathrm{CC}=\mathrm{C} 3$ & -8 & -8.3 & -8.5 & -8.4 & -7.7 & -6.7 & -8.2 & -6.6 & -6.9 \\
\hline 13660041 & $\mathrm{C} 1 \mathrm{C} 2 \mathrm{CC} 3 \mathrm{C} 1 \mathrm{C} 3 \mathrm{C} 4=\mathrm{CC}=\mathrm{CC}=\mathrm{C} 24$ & -6.7 & -8.4 & -8.2 & -8.5 & -7.3 & -7.1 & -8.3 & -6 & -6.7 \\
\hline 13807382 & $C C 1=C C=C C=C 1 C C C C=O$ & -6.8 & -7.1 & -7 & -6.9 & -6.7 & -6.3 & -7.8 & -6 & -6 \\
\hline 14087329 & $\mathrm{C} 1 \mathrm{CC} 2=\mathrm{CC}=\mathrm{CC}=\mathrm{C} 2 \mathrm{C} 1 \mathrm{NO}$ & -6.5 & -7.3 & -7.2 & -7.7 & -7.7 & -6.6 & -8 & -6.4 & -6.2 \\
\hline 195743 & $C C(=O) C C 1=C C=C C=C C 1=O$ & -6.7 & -7.2 & -7.3 & -7.3 & -7.6 & -6.4 & -8 & -6.2 & -7 \\
\hline
\end{tabular}




\begin{tabular}{|c|c|c|c|c|c|c|c|c|c|c|}
\hline 14204944 & $\operatorname{ccccc} 1=C(C(=C C=C 1) O) O$ & -7 & -7.8 & -7.3 & -7.1 & -7.7 & -6.3 & -7.5 & -6.6 & -6 \\
\hline 14384349 & $\mathrm{C} 1 \mathrm{C}=\mathrm{CCC} 1 \mathrm{C} 2=\mathrm{CC}=\mathrm{CC}=\mathrm{C} 2 \mathrm{O}$ & -7.8 & -8.7 & -7.7 & -8.2 & -8 & -6.4 & -8.1 & -6 & -6.9 \\
\hline 14490423 & $\mathrm{C} 1 \mathrm{C} 2 \mathrm{CC} 3 \mathrm{C} 1 \mathrm{C} 3 \mathrm{C} 2 \mathrm{C} 4=\mathrm{CC}=\mathrm{CC}=\mathrm{C} 4$ & -7.7 & -8.6 & -8.4 & -8.2 & -8.2 & -7.1 & -8.4 & -6.1 & -6.4 \\
\hline 14527740 & $\mathrm{CC} 1 \mathrm{CC}=\mathrm{CC} 1 \mathrm{C} 2=\mathrm{CC}=\mathrm{CC}=\mathrm{C} 2$ & -7.6 & -8 & -8.4 & -8.9 & -7.8 & -7.2 & -8.7 & -6.5 & -6.4 \\
\hline 14948280 & $\mathrm{C}=\mathrm{C} 1 \mathrm{CC} 2 \mathrm{CC} 1 \mathrm{C} 3=\mathrm{CC}=\mathrm{CC}=\mathrm{C} 23$ & -7.1 & -8.4 & -7.8 & -7.4 & -7.2 & -7 & -7.7 & -6 & -6.8 \\
\hline 14954003 & $\mathrm{CC} 1=\mathrm{CC}=\mathrm{CCC} 1 \mathrm{C} 2=\mathrm{CC}=\mathrm{CC}=\mathrm{C} 2$ & -6.1 & -8.2 & -7.7 & -7.8 & -8 & -7.2 & -8.8 & -6 & -6 \\
\hline 15209342 & $\operatorname{ccoc}(=0) \operatorname{ccc} 1=\operatorname{cc}(=C C=C 1) F$ & -6.9 & -8.3 & -8.4 & -7.6 & -7.4 & -6.2 & -8 & -6.6 & -6.1 \\
\hline 15327731 & $\mathrm{CC} 1=\mathrm{CC}=\mathrm{C}(\mathrm{C}=\mathrm{C} 1) \mathrm{C}(=\mathrm{O}) \mathrm{C} 2 \mathrm{C}=\mathrm{CC}=\mathrm{C} 2$ & -8.6 & -9.6 & -9.2 & -9.4 & -8.8 & -7.7 & -9.4 & -6.5 & -6.2 \\
\hline 15373214 & $C 1=C C=C(C=C 1) S(=O)(=0) N F$ & -6.1 & -7.6 & -7.1 & -7.4 & -7.4 & -6.4 & -7.3 & -6.8 & -6.1 \\
\hline 15408803 & $\mathrm{C} 1=\mathrm{CC}=\mathrm{C}(\mathrm{C}=\mathrm{C} 1) \mathrm{S}(=\mathrm{NF})(=\mathrm{O}) \mathrm{O}$ & -6.1 & -7.6 & -7.4 & -7.6 & -7 & -6 & -7.4 & -6.1 & -6.5 \\
\hline 15474146 & $\mathrm{C} 1 \mathrm{C}=\mathrm{C} C \mathrm{C} 2 \mathrm{C} 1 \mathrm{C} 2=\mathrm{C} 3 \mathrm{C}=\mathrm{CC}=\mathrm{C} 3$ & -7.6 & -8.3 & -8.2 & -8.1 & -7.4 & -7.1 & -8.5 & -6 & -7.2 \\
\hline 15692112 & $\mathrm{CC}(\mathrm{CC} 1=\mathrm{C}(\mathrm{C}(=\mathrm{CC}=\mathrm{C} 1) \mathrm{O}) \mathrm{O}) \mathrm{NC}$ & -6.3 & -7.5 & -6.8 & -6.6 & -7.5 & -6.1 & -7.4 & -6.2 & -6.3 \\
\hline 15706998 & $C / C=C / C C 1=C C(=O) C=C C 1=O$ & -6.5 & -7.9 & -7.8 & -7.4 & -7.3 & -6.2 & -7.8 & -7.1 & -6.3 \\
\hline 15759874 & $\mathrm{C}=\mathrm{C}=\mathrm{C} 1 \mathrm{CC} 1 \mathrm{C} 2=\mathrm{CC}=\mathrm{CC}=\mathrm{C} 2$ & -7.4 & -7.8 & -8.2 & -7.7 & -7.7 & -6.6 & -8 & -6.4 & -6.6 \\
\hline 15824936 & $\mathrm{C} 1=\mathrm{CC}=\mathrm{C}(\mathrm{C}=\mathrm{C} 1) \mathrm{C}(=\mathrm{O}) \mathrm{CC} 2 \mathrm{C}=\mathrm{CC}=\mathrm{C} 2$ & -7.3 & -9.3 & -9.3 & -9.6 & -8.7 & -7 & -9.4 & -6.4 & -6.5 \\
\hline 16685843 & $\mathrm{CCC} 1=\mathrm{CC}=\mathrm{C} 2 \mathrm{C} 1 \mathrm{C}=\mathrm{CC}=\mathrm{C} 2$ & -7.3 & -7.4 & -7.3 & -7.7 & -7 & -6.7 & -7.8 & -6 & -6.2 \\
\hline 16699325 & $\mathrm{C} 1=\mathrm{CC} 2 \mathrm{C}=\mathrm{C}(\mathrm{C}=\mathrm{C} 2 \mathrm{C}=\mathrm{C} 1) \mathrm{C}(=\mathrm{O}) \mathrm{O}$ & -7.1 & -8 & -8.1 & -8.2 & -8.1 & -7 & -8.3 & -6.1 & -7.6 \\
\hline 17969228 & $\mathrm{CCC}(\mathrm{C} 1=\mathrm{C}(\mathrm{C}(=\mathrm{CC}=\mathrm{C} 1) \mathrm{O}) \mathrm{O}) \mathrm{F}$ & -6.6 & -7.5 & -6.9 & -6.6 & -7.5 & -6 & -7.2 & -6.3 & -6.6 \\
\hline 17969677 & $\operatorname{Ccc}(C) C 1=C(C(=C C=C 1) O) O$ & -6.7 & -7.5 & -6.7 & -6.8 & -7.3 & -6.1 & -7.1 & -6 & -6.3 \\
\hline 18366203 & $\mathrm{C}=\mathrm{CC}(=\mathrm{O}) \mathrm{CC} 1=\mathrm{C}(\mathrm{C}=\mathrm{CC}=\mathrm{C} 1 \mathrm{~F}) \mathrm{F}$ & -6.5 & -7.4 & -7.4 & -7.6 & -7.4 & -6.1 & -7.9 & -6.3 & -6.4 \\
\hline 18972422 & $\mathrm{C} 1=\mathrm{CC}=\mathrm{C} 2 \mathrm{C}(\mathrm{C}(=\mathrm{CC} 2=\mathrm{C} 1) \mathrm{O}) \mathrm{O}$ & -6.4 & -7.5 & -7.4 & -7.5 & -7.7 & -6.3 & -7.8 & -6.2 & -6.7 \\
\hline 19782555 & $\mathrm{C} 1=\mathrm{CC}=\mathrm{C}(\mathrm{C}=\mathrm{C} 1) \mathrm{S}(=\mathrm{O})(=\mathrm{O}) \mathrm{OC}(=\mathrm{O}) \mathrm{O}$ & -6.5 & -7.5 & -7.6 & -7 & -7.6 & -6.3 & -8 & -6.9 & -6 \\
\hline 19783500 & $\mathrm{C} 1=\mathrm{CC}=\mathrm{C} 2 \mathrm{C}(\mathrm{C}=\mathrm{CC} 2=\mathrm{C} 1) \mathrm{S}(=\mathrm{O})(=\mathrm{O}) \mathrm{N}$ & -6.4 & -7.7 & -7.4 & -8 & -7 & -7.1 & -8.1 & -6.7 & -6.1 \\
\hline 19880772 & $\mathrm{C} 1=\mathrm{CC}=\mathrm{C} 2 \mathrm{C}(=\mathrm{C} 1) \mathrm{C}=\mathrm{CN}(\mathrm{O} 2) \mathrm{O}$ & -6.1 & -8 & -7.5 & -7.5 & -7.7 & -6.4 & -8 & -6.2 & -7.1 \\
\hline 19886395 & $\mathrm{COC} 1=\mathrm{CC} 2=\mathrm{C}(\mathrm{C}=\mathrm{C} 2 \mathrm{C}=\mathrm{C} 1) \mathrm{C}(=\mathrm{O}) \mathrm{O}$ & -6.7 & -8 & -7.4 & -7.1 & -7.6 & -6.9 & -7.7 & -6 & -6 \\
\hline 9886408 & $2 \mathrm{CCO}$ & -6.8 & -7.7 & -7.8 & -7.6 & -7.2 & -6.2 & -7.7 & 0.1 & -7 \\
\hline
\end{tabular}




\begin{tabular}{|c|c|c|c|c|c|c|c|c|c|c|}
\hline 19910317 & $\mathrm{C} / \mathrm{C}=\mathrm{C} / \mathrm{C} 1=\mathrm{C}(\mathrm{C}(=\mathrm{CC}=\mathrm{C} 1) \mathrm{O}) \mathrm{O}$ & -6.5 & -7.4 & -6.9 & -6.8 & -7.4 & -6 & -7.3 & -6.4 & -6.5 \\
\hline 20077952 & $C 1=C C(=C(C=C 1 C(C(=O) O) O N) O) O$ & -6.3 & -7.9 & -6.5 & -6.5 & -7.1 & -6.3 & -7 & -7.1 & -6.1 \\
\hline 20221896 & $\mathrm{CcCOC} 1=\mathrm{CC} 2=\mathrm{CC}=\mathrm{CC}=\mathrm{C} 21$ & -6.8 & -8 & -7.9 & -8 & -7.9 & -6.2 & -8 & -6.2 & -6.4 \\
\hline 20279430 & $C 1=C C(=C C 2=C(C=C 21) C(=0) O) O$ & -6.8 & -7.7 & -7.6 & -7 & -7.5 & -6.7 & -7.5 & -6 & -6.8 \\
\hline 20361494 & $\operatorname{ccccc} 1=C(C(=C C=C 1) 00) 00$ & -6 & -6.9 & -7.3 & -6.9 & -7.6 & -6.4 & -7.6 & -7.5 & -6.7 \\
\hline 20507381 & $C 1=C C(=C(C=C 1 C(C C(=0) O) O) O) O$ & -6.1 & -7.8 & -7 & -6.6 & -7.3 & -6.4 & -7.4 & -6.6 & -7 \\
\hline 21219659 & $\mathrm{C} 1=\mathrm{CC}=\mathrm{C}(\mathrm{C}=\mathrm{C} 1) \mathrm{N}(\mathrm{N}) \mathrm{S}(=\mathrm{O})(=\mathrm{O}) \mathrm{O}$ & -6.4 & -7.5 & -6.7 & -7.1 & -7 & -6.2 & -7.4 & -7.2 & -6 \\
\hline 21225956 & $\mathrm{C}=\mathrm{C}(\mathrm{CC} 1=\mathrm{CC}=\mathrm{CC}=\mathrm{C} 1) \mathrm{C}(=\mathrm{O}) \mathrm{N}$ & -7.2 & -7.8 & -8.1 & -7.4 & -7 & -6.6 & -8 & -6.7 & -6 \\
\hline 21433320 & $C 1=C C=C(C=C 1) S(=O)(=O) N=C=N$ & -6.7 & -7.5 & -7.4 & -7.2 & -7.7 & -6.6 & -7.9 & -6.9 & -6.1 \\
\hline 21452091 & $\mathrm{C} 1=\mathrm{CC}=\mathrm{C}(\mathrm{C}=\mathrm{C} 1) \mathrm{C}(\mathrm{F}) \mathrm{S}(=\mathrm{O})(=\mathrm{O}) \mathrm{O}$ & -6.5 & -8.1 & -7.1 & -7.3 & -7.3 & -6.3 & -7.7 & -7 & -6.9 \\
\hline 21521486 & $\operatorname{ccccc} 1=C C=C C(=0) C 1=0$ & -6.1 & -8 & -7.2 & -7.1 & -7.3 & -6.2 & -7.7 & -6.7 & -6.3 \\
\hline 21729606 & $\mathrm{C}=\mathrm{C} 1 \mathrm{CC} 1 \mathrm{CC} 2=\mathrm{CC}=\mathrm{CC}=\mathrm{C} 2$ & -7.5 & -8 & -8 & -7.9 & -7.3 & -6.5 & -7.8 & -6.2 & -6.3 \\
\hline 21896267 & $C 1=C C=C(C=C 1) C(=O) S(=O)(=0) O$ & -6.6 & -8.5 & -7.7 & -7.9 & -7.7 & -6.8 & -7.8 & -7.4 & -6 \\
\hline 22044427 & $\operatorname{CCCCC} 1 \mathrm{C} 2=\mathrm{CC}=\mathrm{CC}=\mathrm{C} 12$ & -7 & -7.7 & -7.9 & -7.6 & -7.2 & -6.3 & -7.7 & -6.1 & -6.1 \\
\hline 22055108 & $\mathrm{CC}(\mathrm{C}) \mathrm{CC} 1=\mathrm{C}(\mathrm{C}(=\mathrm{CC}=\mathrm{C} 1) \mathrm{O}) \mathrm{O}$ & -6.6 & -7.6 & -7 & -6.9 & -7.4 & -6.2 & -7.4 & -6.1 & -7.1 \\
\hline 22171862 & $\mathrm{C} 1 \mathrm{CC} 2=\mathrm{C} 1 \mathrm{C} 3=\mathrm{CC}=\mathrm{CC}=\mathrm{C} 23$ & -7 & -7.5 & -8 & -7.9 & -7.5 & -6.3 & -8.6 & -6.2 & -8 \\
\hline 22215574 & $C 1 C C 2=C(C=C 1 C 2) C(=O) C 3=C C=C C=C 3$ & -8.6 & -8.9 & -9.4 & -9 & -8.5 & -7.8 & -9.3 & -7.3 & -6 \\
\hline 22364268 & $\mathrm{C} 1 \mathrm{C}=\mathrm{CC} 2=\mathrm{C} 1 \mathrm{C}=\mathrm{C}(\mathrm{C}=\mathrm{C} 2) \mathrm{C}(=\mathrm{O}) \mathrm{O}$ & -6.9 & -8.1 & -7.9 & -8.3 & -7.7 & -7 & -8.3 & -6.6 & -6.4 \\
\hline 22395239 & $C 1=C C=C(C=C 1) C(C=O) S(=O)(=0) O$ & -6.6 & -6.7 & -6.4 & -6.8 & -7.2 & -6.3 & -7.5 & -7.5 & -6.1 \\
\hline 22401604 & $\mathrm{C} / \mathrm{C}(=\mathrm{C} / \mathrm{CC}(=\mathrm{C}) \mathrm{C}(=\mathrm{O}) \mathrm{O}) / \mathrm{C}(=\mathrm{O}) \mathrm{Cl}$ & -6.6 & -7.4 & -6.8 & -6.5 & -6.6 & -6 & -7.1 & -6.2 & -6.4 \\
\hline 22798161 & $\mathrm{C} 1=\mathrm{CC}=\mathrm{C}(\mathrm{C}=\mathrm{C} 1) \mathrm{CC}(=\mathrm{O})[\mathrm{C} @ \mathrm{H}](\mathrm{CO}) \mathrm{N}$ & -6.9 & -7.5 & -7.6 & -7.6 & -7.2 & -6.6 & -7.7 & -6.8 & -6.4 \\
\hline 22904532 & $\mathrm{C} 1=\mathrm{CC}(=\mathrm{CC}=\mathrm{C} 1 \mathrm{C}(\mathrm{C}(\mathrm{C}(=\mathrm{O}) \mathrm{O}) \mathrm{O}) \mathrm{O}) \mathrm{F}$ & -7.3 & -7.8 & -7.6 & -7.3 & -7.6 & -6.6 & -7.8 & -6.9 & -6.6 \\
\hline 23335488 & $\mathrm{C} 1 \mathrm{CC} 2=\mathrm{CC}=\mathrm{CC}=\mathrm{C} 2 \mathrm{C} 1 \mathrm{NN}$ & -6.6 & -7.6 & -7.1 & -7.1 & -7.6 & -6.5 & -7.8 & -6.7 & -6.6 \\
\hline 23391769 & $\mathrm{C} 1 \mathrm{C}=\mathrm{CCC} 1 \mathrm{CC} 2=\mathrm{CC}=\mathrm{CC}=\mathrm{C} 2 \mathrm{O}$ & -7.7 & -9 & -8.1 & -8.3 & -8.4 & -6.5 & -8.5 & -6.9 & -6.5 \\
\hline 23392720 & $\mathrm{C} 1=\mathrm{CC}=\mathrm{C}(\mathrm{C}=\mathrm{C} 1) \mathrm{S}(=\mathrm{O}) \mathrm{ONCl}$ & -6.3 & -7.4 & -7 & -7 & -7 & -6 & -7.2 & -6.6 & -6.1 \\
\hline 28297093 & $\mathrm{CC} 1=\mathrm{CC}=\mathrm{CC}=\mathrm{C} 1 \mathrm{CCCON}$ & -6.8 & -6.9 & -6.8 & -6.7 & -6.6 & -6.3 & -7.9 & -6.1 & -6.7 \\
\hline
\end{tabular}




\begin{tabular}{|c|c|c|c|c|c|c|c|c|c|c|}
\hline 29005021 & $\mathrm{C} 1 \mathrm{COC}(=\mathrm{O})[\mathrm{C} @ \mathrm{H}] 1 \mathrm{NCC}(\mathrm{C}(\mathrm{F}) \mathrm{F})(\mathrm{F}) \mathrm{F}$ & -6.6 & -7.8 & -7.2 & -7.3 & -7 & -6.2 & -7.9 & -6.7 & -6.4 \\
\hline 30048061 & $\mathrm{CC}(\mathrm{C}) \mathrm{CC}(=\mathrm{O}) \mathrm{N}[\mathrm{C} @ @ \mathrm{H}](\mathrm{CO}) \mathrm{C}(=\mathrm{O}) \mathrm{O}$ & -6.3 & -7.3 & -6.3 & -6.7 & -6.3 & -6 & -7 & -6.7 & -6.1 \\
\hline 30053902 & $\mathrm{C}([\mathrm{C} @ @ \mathrm{H}](\mathrm{C}(=\mathrm{O}) \mathrm{O}) \mathrm{NC}(=\mathrm{O}) \mathrm{CC}(\mathrm{F})(\mathrm{F}) \mathrm{F}) \mathrm{O}$ & -6.3 & -7.3 & -6.5 & -6.7 & -6.7 & -6 & -7 & -6.7 & -6.6 \\
\hline 45099155 & $\mathrm{C} 1=\mathrm{CC}=\mathrm{C} 2 \mathrm{C}(=\mathrm{C} 1) \mathrm{C}=\mathrm{C} 3 \mathrm{C} 2=\mathrm{CNO} 3$ & -6.2 & -8.4 & -8.5 & -8.2 & -8.5 & -7.1 & -8.8 & -6.3 & -6.5 \\
\hline 53685382 & $\mathrm{C}([\mathrm{C} @ @ \mathrm{H}](\mathrm{C}(=\mathrm{O}) \mathrm{O}) \mathrm{NC}(=\mathrm{O}) \mathrm{C}(\mathrm{F})(\mathrm{F}) \mathrm{F}) \mathrm{C}(=\mathrm{O}) \mathrm{N}$ & -6.5 & -6.9 & -7.1 & -6.4 & -7.3 & -6.2 & -7.2 & -7 & -6.3 \\
\hline 53707866 & $\mathrm{CC}=\mathrm{CC} 1=\mathrm{CC} 2 \mathrm{CCC} 1 \mathrm{C} 2$ & -6.5 & -6.9 & -7.7 & -7.1 & -6.9 & -6.2 & -6.9 & -6.2 & -6.9 \\
\hline 53739682 & $\mathrm{C} 1=\mathrm{CC}(=\mathrm{C}(\mathrm{C}(=\mathrm{C} 1 \mathrm{C}(=\mathrm{O}) \mathrm{F}) \mathrm{F}) \mathrm{F}) \mathrm{F}$ & -6.4 & -8 & -7.7 & -7.6 & -7.8 & -6.3 & -7.8 & -6.2 & -6.2 \\
\hline 53817830 & $\mathrm{CC}=\mathrm{CC} 1 \mathrm{CCC} 2=\mathrm{CC}=\mathrm{CC}=\mathrm{C} 12$ & -6.8 & -7.7 & -8.1 & -8.1 & -7.6 & -6.5 & -8.3 & -6 & -6.1 \\
\hline 53912394 & $\mathrm{CC}=\mathrm{CCC} 1=\mathrm{CC} 2 \mathrm{CCC} 1 \mathrm{C} 2$ & -6.8 & -7.2 & -7.8 & -7.2 & -6.9 & -6.3 & -7.2 & -6.1 & -6.2 \\
\hline 53925996 & $\mathrm{C}=\mathrm{CC}=\mathrm{CC} 1=\mathrm{CC} 2 \mathrm{CCC} 1 \mathrm{C} 2$ & -6.6 & -7.1 & -7.7 & -7.6 & -7.3 & -6.6 & -7.3 & -6.4 & -6.6 \\
\hline 53983408 & $\mathrm{CCC}=\mathrm{CC} 1=\mathrm{CC} 2 \mathrm{CC} 1 \mathrm{C}=\mathrm{C} 2$ & -7 & -7.3 & -7.8 & -7.3 & -7.3 & -6.4 & -7.4 & -6 & -6.2 \\
\hline 54103613 & $\mathrm{CC}=\mathrm{CCC} 1=\mathrm{C}(\mathrm{C}=\mathrm{CC}(=\mathrm{C} 1) \mathrm{O}) \mathrm{O}$ & -6.6 & -7.5 & -7.5 & -7 & -7 & -6.1 & -7.4 & -7 & -6.3 \\
\hline 54110535 & $\mathrm{CCOC} 1 \mathrm{CC} 2=\mathrm{CC}=\mathrm{CC}=\mathrm{C} 2 \mathrm{C} 1$ & -6.4 & -7.3 & -7.9 & -7.5 & -7.6 & -6.1 & -8.1 & -6 & -6.4 \\
\hline 54193313 & $\mathrm{C} 1 \mathrm{CC} 2=\mathrm{CC}=\mathrm{CC}=\mathrm{C} 2 \mathrm{C} 1 \mathrm{~N}=\mathrm{O}$ & -6.4 & -7.1 & -6.9 & -7.5 & -7.2 & -6.1 & -7.8 & -6.1 & -6.3 \\
\hline 54197370 & $\mathrm{C} 1=\mathrm{CC}=\mathrm{C}(\mathrm{C}=\mathrm{C} 1) \mathrm{S}(=\mathrm{O})(=\mathrm{O}) \mathrm{N}(\mathrm{O}) \mathrm{F}$ & -6.5 & -7.3 & -7.1 & -7.2 & -7.5 & -6.8 & -7.5 & -6.7 & -6.2 \\
\hline 54380049 & $C C=C C 1=C(C(=C C=C 1) O) O$ & -6.5 & -7.4 & -6.9 & -6.8 & -7.4 & -6 & -7.3 & -6.4 & -6.5 \\
\hline 54541314 & $C C=C C 1=C(C(=C C=C 1) O) F$ & -6.3 & -7.5 & -7.3 & -7 & -7.4 & -6.4 & -7.5 & -6.1 & -6.2 \\
\hline 54542571 & $\mathrm{CCC}=\mathrm{CC} 1=\mathrm{CC} 2 \mathrm{CCC} 1 \mathrm{C} 2$ & -7 & -7.1 & -7.8 & -7.2 & -7.2 & -6.1 & -7.3 & -6 & -6 \\
\hline 54776127 & $\mathrm{CC} 1=\mathrm{CC}=\mathrm{CC}=\mathrm{C} 1 \mathrm{C} 2 \mathrm{CC} 2 \mathrm{CO}$ & -7.1 & -7.5 & -7.2 & -7.3 & -7.1 & -6.5 & -7.9 & -6 & -7 \\
\hline 55268119 & $\mathrm{C} 1=\mathrm{CC}=\mathrm{C} 2 \mathrm{C}(=\mathrm{C} 1) \mathrm{C}=\mathrm{C} 2 \mathrm{CCN}$ & -6.7 & -7.7 & -7.8 & -7.6 & -7.1 & -6.3 & -7.8 & -6.2 & -6.8 \\
\hline 57098943 & $\operatorname{cccc}(C C 1=C(C(=C C=C 1) O) O) O$ & -6 & -8 & -7.2 & -7.1 & -8.1 & -6.3 & -7.7 & -6.5 & -6.2 \\
\hline 57126213 & $\mathrm{C} 1=\mathrm{CC}=\mathrm{C} 2 \mathrm{C}(=\mathrm{C} 1) \mathrm{C}=\mathrm{CN} 2 \mathrm{OO}$ & -6 & -7.7 & -7.3 & -7 & -7.3 & -6.3 & -7.3 & -6.1 & -6.4 \\
\hline 57219742 & $\mathrm{CCCC}=\mathrm{C} 1 \mathrm{CC} 2=\mathrm{CCC} 1 \mathrm{C} 2$ & -7 & -7.1 & -7.5 & -7.1 & -7.1 & -6.3 & -7.4 & -6.3 & -6.1 \\
\hline 57254362 & $C 1=C C=C(C=C 1) S(=O)(=0) N N=O$ & -6.3 & -7.9 & -7.3 & -7.2 & -7.7 & -6.6 & -7.8 & -7 & -6.3 \\
\hline 57271792 & $\mathrm{CCC}=\mathrm{C} 1 \mathrm{CC} 2=\mathrm{CCC} 1 \mathrm{C} 2$ & -6.7 & -6.8 & -7.2 & -6.8 & -6.9 & -6 & -7.1 & -6 & -6.8 \\
\hline 57470122 & $C 1=C C=C(C=C 1) S(=O)(=O) N(F) F$ & -6.5 & -7.7 & -7 & -7.3 & -7.6 & -6.4 & -7.6 & -6.7 & -6.1 \\
\hline
\end{tabular}




\begin{tabular}{|c|c|c|c|c|c|c|c|c|c|c|}
\hline 58083757 & $\mathrm{C} 1 \mathrm{C}=\mathrm{C} 1 \mathrm{CCC} 2=\mathrm{CC}=\mathrm{CC}=\mathrm{C} 2$ & -7 & -7.9 & -7.9 & -7.7 & -7 & -6.4 & -7.8 & -6.2 & -6.1 \\
\hline 59910019 & $\mathrm{C}[\mathrm{C} @ @ \mathrm{H}](\mathrm{CC} 1=\mathrm{CC}=\mathrm{C}(\mathrm{C}=\mathrm{C} 1) \mathrm{O}) \mathrm{CC}(=\mathrm{O}) \mathrm{O}$ & -7.3 & -7.6 & -7.4 & -7.5 & -7.7 & -7 & -7.5 & -6.7 & -6 \\
\hline 59922559 & $C=C C 1 C C 2=C C=C C=C 2 C 1=O$ & -6.1 & -8.3 & -8.2 & -8.2 & -8.2 & -6.7 & -8.5 & -6 & -6.2 \\
\hline 59930519 & $\mathrm{C}=\mathrm{CC} 1 \mathrm{CC} 2=\mathrm{CC}=\mathrm{CC}=\mathrm{C} 2 \mathrm{C} 1$ & -6.8 & -7.4 & -8.1 & -7.5 & -7.5 & -6.5 & -7.9 & -6 & -6.4 \\
\hline 61312351 & $\operatorname{COC}(=\mathrm{O}) \mathrm{CNC} 1=\mathrm{NC}=\mathrm{C}(\mathrm{C}=\mathrm{C} 1) \mathrm{F}$ & -6.1 & -7.7 & -7.2 & -6.8 & -7.2 & -6 & -7.2 & -6.9 & -6.1 \\
\hline 61499672 & $C C(C(=O) O) N C C 1=C(C=C C=C 1 F) F$ & -7.1 & -8 & -7.5 & -7.7 & -7.9 & -7 & -8.1 & -6.2 & -6.1 \\
\hline 62366913 & $\mathrm{CC} 1=\mathrm{CC}=\mathrm{CC}=\mathrm{C} 1 \mathrm{CCCNN}$ & -7.1 & -7.1 & -6.9 & -6.7 & -6.7 & -6.5 & -7.9 & -6.2 & -6.7 \\
\hline 65805082 & $\mathrm{C} 1 \mathrm{CNC} 1 \mathrm{CCC} 2=\mathrm{CC}=\mathrm{CC}=\mathrm{C} 2$ & -7.1 & -8.1 & -8.1 & -7.8 & -7.5 & -6.4 & -7.8 & -6.6 & -6 \\
\hline 65810874 & $\mathrm{C} 1=\mathrm{CC}(=\mathrm{C}(\mathrm{C}(=\mathrm{C} 1 \mathrm{C}(\mathrm{C}(=\mathrm{O}) \mathrm{O}) \mathrm{O}) \mathrm{F}) \mathrm{F}) \mathrm{F}$ & -6.6 & -7.7 & -7.1 & -7.5 & -7.8 & -6.7 & -7.9 & -6.3 & -6.6 \\
\hline 66701678 & $C C(=C(C 1=C C=C C=C 1) O) O$ & -6.8 & -7.6 & -7.4 & -7.3 & -7 & -6 & -7.1 & -6.1 & -6.1 \\
\hline 67254952 & $C C 1=C C(=C(C=C 1) O) C[C @ @](C(=O) O) N$ & -6.1 & -7.5 & -7.2 & -7 & -7.2 & -7.2 & -8 & -6.9 & -7.3 \\
\hline 67644608 & $C C=C C 1=C C(=0) C=C C 1=O$ & -6.8 & -7.4 & -7.2 & -7.3 & -7 & -6 & -7.4 & -6.9 & -6.1 \\
\hline 67670465 & $\mathrm{C} 1=\mathrm{CC}=\mathrm{C}(\mathrm{C}=\mathrm{C} 1) \mathrm{C} 2=\mathrm{CC} 2 \mathrm{C}(=\mathrm{O}) \mathrm{O}$ & -6.9 & -8.4 & -8.2 & -7.8 & -8 & -7 & -8 & -6.7 & -6.2 \\
\hline 67814057 & $C C(=C(C C 1=C C=C C=C 1) O) O$ & -7.1 & -8.2 & -7.3 & -7.5 & -7.1 & -6.3 & -7.5 & -6.2 & -6.6 \\
\hline 67862673 & $\mathrm{C} 1=\mathrm{CC}=\mathrm{C}(\mathrm{C}=\mathrm{C} 1) \mathrm{C}(=\mathrm{O}) \mathrm{C} 2=\mathrm{C} 3 \mathrm{C}=\mathrm{C} 3 \mathrm{C}=\mathrm{C} 2$ & -8.2 & -10 & -9.3 & -9.9 & -9.1 & -7.4 & -9.5 & -7.1 & -6.1 \\
\hline 68098372 & $\mathrm{C} 1=\mathrm{CC}=\mathrm{C}(\mathrm{C}=\mathrm{C} 1) \mathrm{S}(=\mathrm{O})(=\mathrm{O}) \mathrm{CN}=\mathrm{N}$ & -6.4 & -7.1 & -7.2 & -6.9 & -7.3 & -6.5 & -7.7 & -7 & -6 \\
\hline 68102430 & $\mathrm{C} 1=\mathrm{CC}(=\mathrm{C}(\mathrm{C}=\mathrm{C} 1 \mathrm{C}(\mathrm{C}(=\mathrm{O}) \mathrm{O}) \mathrm{O}) \mathrm{O}) \mathrm{F}$ & -6.3 & -7.5 & -6.7 & -7 & -7.2 & -6.4 & -7.6 & -7 & -6.5 \\
\hline 68530213 & $\mathrm{C} 1=\mathrm{CC}(=\mathrm{C}(\mathrm{C}(=\mathrm{C} 1 \mathrm{CC}(=\mathrm{O}) \mathrm{O}) \mathrm{O}) \mathrm{F}) \mathrm{F}$ & -6 & -8 & -7 & -7.1 & -7.5 & -6.3 & -7.7 & -7 & -7 \\
\hline 68892867 & $\mathrm{C} 1 \mathrm{CC} 1 \mathrm{CCC} 2=\mathrm{CC}=\mathrm{CC}=\mathrm{C} 2 \mathrm{~F}$ & -7.3 & -7.6 & -8 & -7.7 & -7.3 & -6.4 & -7.9 & -6.4 & -6.5 \\
\hline 68971788 & $\mathrm{C} 1=\mathrm{CC}=\mathrm{C}(\mathrm{C}=\mathrm{C} 1) \mathrm{S}(=\mathrm{O})(=\mathrm{O}) \mathrm{N}(\mathrm{O}) \mathrm{O}$ & -6.3 & -7.4 & -6.7 & -6.8 & -7.5 & -6.6 & -7.6 & -7.1 & -6.8 \\
\hline 69106651 & $\mathrm{C} 1 \mathrm{CC} 2 \mathrm{CC} 1 \mathrm{C} 3=\mathrm{C} 2 \mathrm{C}=\mathrm{C}(\mathrm{C}=\mathrm{C} 3) \mathrm{C}(=\mathrm{O}) \mathrm{N}$ & -7.4 & -9.3 & -8.5 & -8.7 & -8.5 & -7.6 & -8.5 & -6.9 & -6.3 \\
\hline 69115977 & $\mathrm{C} 1=\mathrm{CC}=\mathrm{C}(\mathrm{C}=\mathrm{C} 1) \mathrm{C} 2 \mathrm{C}=\mathrm{CC}(=\mathrm{O}) \mathrm{N} 2$ & -7.5 & -8.4 & -8.1 & -8 & -7.5 & -7 & -8.5 & -6.5 & -6.7 \\
\hline 69169673 & $C C=C(C C 1=C C=C C=C 1) C(=O) N$ & -7.9 & -7.7 & -8.7 & -8 & -7.9 & -6.4 & -8.4 & -6.5 & -6.4 \\
\hline 69255777 & $\operatorname{CccC}(C) C 1=C(C(=C C=C 1) O) O$ & -7 & -7.8 & -7.1 & -6.9 & -7.9 & -6.6 & -7.6 & -6.1 & -6.5 \\
\hline 69404194 & $\mathrm{CC}(=\mathrm{C}([\mathrm{C} @ \mathrm{H}]([\mathrm{C} @ @ \mathrm{H}] 1[\mathrm{C} @ @ \mathrm{H}]$ & -6.7 & -6.4 & -6.7 & -7.4 & -6.8 & -6.3 & -6.9 & -6.9 & -6.4 \\
\hline 9424111 & $\operatorname{cccccc} 1 \mathrm{CC}(=0) \mathrm{NC} 1$ & -6.5 & -6.7 & -6.7 & -6.5 & -6.5 & -6 & -6.9 & -6.2 & -6 \\
\hline
\end{tabular}




\begin{tabular}{|c|c|c|c|c|c|c|c|c|c|c|}
\hline 70063405 & $\mathrm{C} 1=\mathrm{CC}=\mathrm{C} 2 \mathrm{C} 3 \mathrm{C}(=\mathrm{CC} 2=\mathrm{C} 1) \mathrm{C}=\mathrm{CN} 3$ & -6.6 & -8.2 & -8.1 & -8.4 & -8.5 & -6.9 & -8.8 & -6 & -6.1 \\
\hline 70560901 & $\operatorname{ccccc} 1=C C(=O) C=C C 1=N$ & -7.1 & -7.6 & -7.5 & -7.2 & -6.9 & -6.2 & -7.5 & -6.7 & -6.5 \\
\hline 70587063 & $\mathrm{C} 1=\mathrm{CC}=\mathrm{C}(\mathrm{C}=\mathrm{C} 1) \mathrm{C}(=\mathrm{O}) \mathrm{C} 2=\mathrm{CC} 2 \mathrm{O}$ & -7.1 & -8.5 & -8 & -8.1 & -7.5 & -6.3 & -7.9 & -6.6 & -6.8 \\
\hline 71756609 & $\mathrm{C} 1 \mathrm{CC} 2=\mathrm{CC}=\mathrm{CC}=\mathrm{C} 2 \mathrm{C} 3 \mathrm{C} 1 \mathrm{C} 3 \mathrm{CN}$ & -6.6 & -7.8 & -7.9 & -7.8 & -7.8 & -7.7 & -8.4 & -6.3 & -6 \\
\hline 72222744 & $C 1 C C 1 C C 2=C(C(=C C=C 2) O) F$ & -6.4 & -7.7 & -7.5 & -7.5 & -7.4 & -6.7 & -7.6 & -6.3 & -6.1 \\
\hline 73120763 & $\mathrm{CCC}=\mathrm{CC}(\mathrm{C} 1 \mathrm{C}=\mathrm{CC}(=\mathrm{O}) \mathrm{O} 1) \mathrm{O}$ & -6.8 & -7.1 & -7 & -7 & -6.9 & -6 & -7.2 & -7.1 & -6.1 \\
\hline 73746948 & $C 1 C C 2=C 1 C C 2 C 3=C C=C C=C 3$ & -8.1 & -8.5 & -8.6 & -8.6 & -8.1 & -6.9 & -8.9 & -6.8 & -6 \\
\hline 73910492 & $\mathrm{CC}(\mathrm{C}) \mathrm{CC}(=\mathrm{O}) \mathrm{N}[\mathrm{C} @ @ \mathrm{H}](\mathrm{CC}(=\mathrm{O}) \mathrm{O}) \mathrm{C}(=\mathrm{O}) \mathrm{O}$ & -6.2 & -7.2 & -7.1 & -6.4 & -7 & -6.6 & -7.4 & -7.5 & -6 \\
\hline 79367162 & $C 1=C C(=C(C(=C 1 C(C(=O) O) F) F) F) F$ & -6.5 & -8.1 & -7.4 & -7.9 & -8 & -6.8 & -8.5 & -6.9 & -6.9 \\
\hline 79722928 & $\operatorname{CcccC}(=0) C 1=N C=C(C=C 1) F$ & -6.4 & -7.9 & -7.4 & -7.5 & -7.5 & -6 & -7.5 & -6.6 & -6.4 \\
\hline 80378637 & $\operatorname{CCC}(=0) C C 1=C(C=C C=C 1 F) F$ & -6.5 & -7.3 & -7.4 & -7.5 & -7.3 & -6.1 & -7.8 & -6.2 & -6.3 \\
\hline 81009944 & $\mathrm{CC} 1=\mathrm{CC}=\mathrm{CC}=\mathrm{C} 1 \mathrm{C} 2 \mathrm{CCC} 2 \mathrm{CN}$ & -6.8 & -7.6 & -7.5 & -6.9 & -7.5 & -7 & -8.6 & -6.1 & -6.4 \\
\hline 81644550 & $\mathrm{C} 1 \mathrm{CC} 2=\mathrm{CC}=\mathrm{CC}=\mathrm{C} 2 \mathrm{C} 3 \mathrm{C} 1 \mathrm{C} 3 \mathrm{CO}$ & -6 & -7.9 & -7.9 & -7.7 & -7.8 & -7.6 & -8.6 & -6.3 & -6.1 \\
\hline 82396082 & $C 1=C C=C(C(=C 1) C C 2 C(=O) N C(=O) O 2) N$ & -7.7 & -8.4 & -7.9 & -7.8 & -8.3 & -7.2 & -8.5 & -6.1 & -6.2 \\
\hline 84769930 & $\mathrm{C} 1=\mathrm{CC}(=\mathrm{C}(\mathrm{C}(=\mathrm{C} 1 \mathrm{CC}(=\mathrm{O}) \mathrm{O}) \mathrm{O}) \mathrm{F}) \mathrm{O}$ & -6.1 & -8.3 & -6.4 & -6.7 & -7.4 & -6.1 & -7.3 & -6.6 & -6.1 \\
\hline 84819575 & $\mathrm{C} 1 \mathrm{CC} 1 \mathrm{CCC} 2=\mathrm{CC}=\mathrm{CC}=\mathrm{C} 2 \mathrm{O}$ & -7 & -7.8 & -7.5 & -7.5 & -7.6 & -6.3 & -7.7 & -6.7 & -6.6 \\
\hline 85085291 & $\mathrm{CC} 1 \mathrm{C}=\mathrm{CCC} 1 \mathrm{C} 2=\mathrm{CC}=\mathrm{CC}=\mathrm{C} 2$ & -7.3 & -7.9 & -8.3 & -8.8 & -7.8 & -6.7 & -8.6 & -6.8 & -6.6 \\
\hline 85540217 & $C=C C(=O) C 1=C C=C C=C C 1=O$ & -6.4 & -7.5 & -7.3 & -7.5 & -7.8 & -6.3 & -7.6 & -6.1 & -6.4 \\
\hline 85549715 & $\mathrm{C}=\mathrm{CC} 1 \mathrm{CC} 2=\mathrm{CC}=\mathrm{CC}=\mathrm{C} 2 \mathrm{C} 1 \mathrm{O}$ & -6.5 & -7.4 & -6.9 & -7 & -7.5 & -6.3 & -7.8 & -6.1 & -7 \\
\hline 85967923 & $\mathrm{C} 1=\mathrm{CC}=\mathrm{C}(\mathrm{C}=\mathrm{C} 1)[\mathrm{N}+](=\mathrm{C}[\mathrm{N}+](=\mathrm{O})[\mathrm{O}-])[\mathrm{O}-]$ & -7.1 & -8.6 & -8 & -8 & -7.9 & -6.4 & -8 & -6.8 & -6.3 \\
\hline 85991543 & $C C 1=C C=C(C=C 1) C(=O) C 2 C C 2=C$ & -7 & -9.1 & -8.6 & -8.8 & -8.1 & -7.3 & -8.6 & -6.5 & -6 \\
\hline 86023307 & $\mathrm{C} 1 \mathrm{CC} 1 \mathrm{CCC} 2=\mathrm{CC}=\mathrm{CC}=\mathrm{C} 2 \mathrm{~N}$ & -6.4 & -7.9 & -7.6 & -7.5 & -7.4 & -6.3 & -7.9 & -6.1 & -6 \\
\hline 86132247 & $\mathrm{C} 1 \mathrm{CC} 2 \mathrm{CCC} 1 \mathrm{C} 2=\mathrm{C} 3 \mathrm{C}=\mathrm{CC}=\mathrm{C} 3$ & -7.3 & -8.5 & -7.5 & -7.8 & -7.4 & -6.6 & -6.9 & -6.7 & -6.3 \\
\hline 86177481 & $\mathrm{C}=\mathrm{C} 1 \mathrm{C}=\mathrm{CCCC} 1 \mathrm{C} 2=\mathrm{CC}=\mathrm{CC}=\mathrm{C} 2$ & -7.4 & -8.6 & -8.6 & -8.5 & -7.7 & -7 & -9 & -6.3 & -7 \\
\hline 86306285 & $\mathrm{C}([\mathrm{C} @ @ \mathrm{H}](\mathrm{C}(\mathrm{C}(\mathrm{F})(\mathrm{F}) \mathrm{F}) \mathrm{C}(\mathrm{F})(\mathrm{F}) \mathrm{F}) \mathrm{O}) \mathrm{C}(=\mathrm{O}) \mathrm{O}$ & -6.5 & -7.6 & -7.4 & -6.7 & -7.4 & -6.1 & -7.4 & -6.4 & -7.7 \\
\hline 86337526 & $\mathrm{C} 1=\mathrm{CC}=\mathrm{C}(\mathrm{C}=\mathrm{C} 1) \mathrm{CC}(=\mathrm{O})[\mathrm{C} @ \mathrm{H}](\mathrm{CO}) \mathrm{O}$ & -6.8 & -7.6 & -7.6 & -7.6 & -7.3 & -6.5 & -7.6 & -6.8 & -6.4 \\
\hline
\end{tabular}




\begin{tabular}{|c|c|c|c|c|c|c|c|c|c|c|}
\hline 86715115 & $\mathrm{C} 1 \mathrm{CC} 1 \mathrm{COC}(=\mathrm{O}) \mathrm{C} 2=\mathrm{NC}=\mathrm{C}(\mathrm{C}=\mathrm{C} 2) \mathrm{O}$ & -6 & -8.1 & -7.4 & -7.5 & -7.5 & -6 & -7.4 & -6.6 & -6 \\
\hline 87842741 & $\mathrm{C} 1=\mathrm{CC}=\mathrm{C} 2 \mathrm{C}(\mathrm{C}=\mathrm{CC} 2=\mathrm{C} 1) \mathrm{C}(=\mathrm{O}) \mathrm{NO}$ & -6.8 & -8.3 & -7.7 & -8.1 & -8.3 & -7.5 & -9.1 & -6.7 & -7.3 \\
\hline 88445062 & $C 1=C(C(=C C(=C 1 C(=0) O) O) O) C C=C=O$ & -6.7 & -7.5 & -6.9 & -6.8 & -7.3 & -6.9 & -7.5 & -6.3 & -6.3 \\
\hline 88672539 & $\mathrm{C} 1=\mathrm{CC}=\mathrm{C}(\mathrm{C}=\mathrm{C} 1) \mathrm{S}(=\mathrm{O})(=\mathrm{O}) \mathrm{ON}=\mathrm{O}$ & -6.3 & -7.8 & -7.4 & -6.9 & -7.4 & -6.2 & -7.7 & -7 & -6.7 \\
\hline 89008217 & $C C 1=C C=C C=C 1 C C C=C=O$ & -7.1 & -7.4 & -7.4 & -7.2 & -7.2 & -6.7 & -8 & -6.2 & -6 \\
\hline 89028635 & $C=C(C C C 1=C C(=C C=C 1) O) O$ & -6.5 & -7.5 & -7.3 & -6.9 & -7.5 & -6.1 & -7.4 & -6.2 & -6.6 \\
\hline 89088385 & $\mathrm{CC} 1=\mathrm{CC}=\mathrm{CC}=\mathrm{C} 1 \mathrm{C} 2 \mathrm{CC}=\mathrm{NO} 2$ & -7 & -7.9 & -7.1 & -7.5 & -7.4 & -6.3 & -8.4 & -6.3 & -6.5 \\
\hline 89402374 & $C C 1=C C(=C C=C 1) C N C(=O) C C O$ & -6.7 & -8.1 & -8.1 & -7.6 & -7.6 & -6.8 & -8.5 & -6.7 & -6 \\
\hline 90255515 & $\mathrm{C} 1=\mathrm{CC}(=\mathrm{O}) \mathrm{OC} 2=\mathrm{CC}(=\mathrm{C}(\mathrm{C}=\mathrm{C} 21) \mathrm{F}) \mathrm{F}$ & -6.9 & -8.9 & -8 & -8.4 & -7.9 & -7.1 & -8.9 & -6.1 & -6.3 \\
\hline 90444348 & $\mathrm{C}[\mathrm{C} @ @ \mathrm{H}](\mathrm{CCC} 1=\mathrm{CC}=\mathrm{C}(\mathrm{C}=\mathrm{C} 1) \mathrm{O}) \mathrm{C}(=\mathrm{O}) \mathrm{O}$ & -6.8 & -8.4 & -7.9 & -7.5 & -7.3 & -6.9 & -7.8 & -7 & -6 \\
\hline 90762075 & $\mathrm{C}=\mathrm{CC} 1 \mathrm{CC} 2=\mathrm{CC}=\mathrm{CC}=\mathrm{C} 2 \mathrm{C} 1 \mathrm{~N}$ & -6.3 & -7.6 & -6.7 & -6.4 & -7.3 & -6.4 & -7.6 & -6 & -6.6 \\
\hline 91229800 & $\mathrm{C} 1 \mathrm{CC} 2 \mathrm{CC} 1 \mathrm{CC} 2 \mathrm{C} 3=\mathrm{CCC}=\mathrm{C} 3$ & -7.9 & -8.1 & -8.5 & -7.7 & -7.8 & -6.8 & -8 & -7 & -6.2 \\
\hline 91454738 & $\mathrm{CC} 1=\mathrm{CCC}=\mathrm{CC} 1 \mathrm{C} 2=\mathrm{CC}=\mathrm{CC}=\mathrm{C} 2$ & -6.3 & -8.4 & -8.2 & -8.5 & -8 & -6.5 & -9 & -6 & -6.1 \\
\hline 92977874 & CCCC[C@@H]1CC[C@H](N1)C(=O)N & -6.3 & -7 & -6.8 & -6.8 & -7 & -6.2 & -7.3 & -6.9 & -6 \\
\hline 94253908 & $\mathrm{C}[\mathrm{C} @ @ \mathrm{H}](\mathrm{CC} 1=\mathrm{CC}(=\mathrm{CC}=\mathrm{C} 1) \mathrm{O}) \mathrm{CC}(=\mathrm{O}) \mathrm{O}$ & -6.9 & -7.7 & -7.6 & -6.9 & -7.7 & -7 & -7.8 & -7.2 & -6 \\
\hline 96125788 & $\mathrm{CC} 1=\mathrm{CC}(=\mathrm{C}(\mathrm{C}=\mathrm{C} 1) \mathrm{O}) \mathrm{C}[\mathrm{C} @ @ \mathrm{H}](\mathrm{C}(=\mathrm{O}) \mathrm{O}) \mathrm{O}$ & -6.1 & -7.3 & -7.2 & -7.1 & -7.3 & -7.1 & -8 & -6.8 & -7.4 \\
\hline 96771609 & $\mathrm{CCC} 1=\mathrm{CC}(=\mathrm{C}(\mathrm{C}=\mathrm{C} 1) \mathrm{O}) \mathrm{C}[\mathrm{C} @ @ \mathrm{H}](\mathrm{C}) \mathrm{C}(=\mathrm{O}) \mathrm{O}$ & -6 & -8.1 & -7.8 & -7.6 & -7.7 & -7.5 & -8.4 & -6.2 & -6.4 \\
\hline 96777923 & $\mathrm{CC}[\mathrm{C} @ @ \mathrm{H}](\mathrm{CC}(=\mathrm{O}) \mathrm{O}) \mathrm{C} 1=\mathrm{C}(\mathrm{C}=\mathrm{CC}(=\mathrm{C} 1) \mathrm{F}) \mathrm{O}$ & -6.6 & -7.6 & -7.3 & -7.3 & -7.7 & -6.8 & -8.1 & -6 & -6.7 \\
\hline 96930715 & $\mathrm{C}([\mathrm{C} @ @ \mathrm{H}](\mathrm{C}(=\mathrm{C}(\mathrm{F}) \mathrm{F}) \mathrm{C}(=\mathrm{O}) \mathrm{O}) \mathrm{F}) \mathrm{C}(\mathrm{F})(\mathrm{F}) \mathrm{F}$ & -6.6 & -7.6 & -7 & -7.2 & -7.2 & -6.3 & -7.8 & -6.8 & -7.1 \\
\hline 101040094 & $C / C=C / C 1=C C(=O) C=C C 1=O$ & -6.8 & -7.4 & -7.2 & -7.3 & -7 & -6 & -7.4 & -6.9 & -6.1 \\
\hline 101452601 & $\operatorname{CCC}(=0) O C 1=C C(=C(C=C 1) O) F$ & -6.5 & -7.8 & -7.4 & -7.4 & -7 & -6.1 & -7.4 & -6.9 & -6 \\
\hline 101889682 & $\mathrm{C}=\mathrm{C} 1 \mathrm{CCCC} 1 \mathrm{C} 2=\mathrm{CC}=\mathrm{CO} 2$ & -6.4 & -7 & -7 & -7 & -6.9 & -6.2 & -7.8 & -6.2 & -6.2 \\
\hline 102208315 & $\mathrm{CC}(\mathrm{C}) \mathrm{C} 1=\mathrm{CC}(\mathrm{C}(=\mathrm{CC}=\mathrm{C} 1) \mathrm{O}) \mathrm{O}$ & -6.1 & -7.3 & -7.2 & -7.1 & -7.3 & -6.5 & -7.8 & -6.1 & -6.1 \\
\hline 102289708 & $\mathrm{C} 1 \mathrm{C} 2 \mathrm{CC} 3=\mathrm{CC}=\mathrm{CC}=\mathrm{C} 3 \mathrm{C} 1 \mathrm{C} 2=\mathrm{O}$ & -6.9 & -8.1 & -7.7 & -7.9 & -7.6 & -7.4 & -8.1 & -6.2 & -6.1 \\
\hline 102392185 & $\mathrm{C} 1=\mathrm{CC}(\mathrm{C}=\mathrm{C} 1) \mathrm{C}(=\mathrm{O}) \mathrm{OC} 2=\mathrm{CN}=\mathrm{CC}=\mathrm{C} 2$ & -7 & -9.2 & -7.7 & -8.3 & -7.6 & -6.5 & -8 & -7.5 & -6.3 \\
\hline 3309153 & $\mathrm{C}([\mathrm{C} @ @ \mathrm{H}](\mathrm{C}(=\mathrm{O}) \mathrm{O}) \mathrm{NC}(=\mathrm{O}) \mathrm{C}(\mathrm{C}$ & -6.7 & -8.4 & -7.4 & -7.6 & -7.6 & -7.1 & -7.7 & -6.5 & -7 \\
\hline
\end{tabular}




\begin{tabular}{|c|c|c|c|c|c|c|c|c|c|c|}
\hline 105432192 & $\mathrm{CC} 1=\mathrm{CC}=\mathrm{CC}=\mathrm{C} 1 \mathrm{C} 2 \mathrm{CCON} 2$ & -7.3 & -7.9 & -7.2 & -7.5 & -7.4 & -6.6 & -8.4 & -6.4 & -6.1 \\
\hline 105432198 & $\mathrm{CC} 1=\mathrm{CC}=\mathrm{CC}=\mathrm{C} 1 \mathrm{C} 2 \mathrm{CCNO} 2$ & -7.3 & -7.3 & -7.6 & -7.5 & -7.4 & -6.4 & -8.2 & -6.2 & -6.9 \\
\hline 105436620 & $\mathrm{CC} 1=\mathrm{CC}=\mathrm{CC}=\mathrm{C} 1 \mathrm{C} 2 \mathrm{CCC} 2 \mathrm{CO}$ & -7 & -7.6 & -7.2 & -6.8 & -7.4 & -6.9 & -8.6 & -6 & -6.5 \\
\hline 108052857 & $\mathrm{C}([\mathrm{C} @ @ \mathrm{H}](\mathrm{C}(=\mathrm{O}) \mathrm{O}) \mathrm{NC}(=\mathrm{O}) \mathrm{C}(\mathrm{C}(\mathrm{F}) \mathrm{F})(\mathrm{F}) \mathrm{F}) \mathrm{O}$ & -6.8 & -7.6 & -6.7 & -6.7 & -6.9 & -6.3 & -7.1 & -6.4 & -6.5 \\
\hline 108053147 & $C([C @ @](C(=O) O) N C(=O) C(C(F) F)(F) F) C(=O) O$ & -6.8 & -7.5 & -7.5 & -7.1 & -7.4 & -6.8 & -7.6 & -7 & -6.1 \\
\hline 108053300 & $\mathrm{C}([\mathrm{C} @ @ \mathrm{H}](\mathrm{C}(=\mathrm{O}) \mathrm{O}) \mathrm{O}) \mathrm{NC}(=\mathrm{O}) \mathrm{C}(\mathrm{C}(\mathrm{F}) \mathrm{F})(\mathrm{F}) \mathrm{F}$ & -6.4 & -7.7 & -7.3 & -6.8 & -7.1 & -6.4 & -7.3 & -6.6 & -6.5 \\
\hline 108093548 & $\mathrm{C}([\mathrm{C} @ @ \mathrm{H}](\mathrm{C}(=\mathrm{O}) \mathrm{O}) \mathrm{O}) \mathrm{NC}(=\mathrm{O}) \mathrm{C}(\mathrm{C}(\mathrm{F})(\mathrm{F}) \mathrm{F})(\mathrm{F}) \mathrm{F}$ & -6.7 & -8 & -7.7 & -7.3 & -7.4 & -6.6 & -7.4 & -6.7 & -6.9 \\
\hline 114978538 & $\mathrm{C \# CC}(=\mathrm{O}) \mathrm{CC} 1=\mathrm{C}(\mathrm{C}=\mathrm{CC}=\mathrm{C} 1 \mathrm{~F}) \mathrm{F}$ & -6.5 & -7.3 & -7.6 & -7.7 & -7.5 & -6.2 & -7.7 & -6.3 & -6.7 \\
\hline 116605120 & $\operatorname{Ccccc}(=0) C 1=N C=C(C=C 1) N$ & -6 & -8 & -7 & -7.3 & -7 & -6 & -7.1 & -6.8 & -6.1 \\
\hline 117287560 & $C 1=C(C(=C C(=C 1 C(=0) O) O) O) C C O$ & -6 & -7 & -6.2 & -6.1 & -6.7 & -6.4 & -6.9 & -6 & -6.1 \\
\hline 117292284 & $\mathrm{C} 1=\mathrm{CC}(=\mathrm{C}(\mathrm{C}(=\mathrm{C} 1 \mathrm{C}(\mathrm{C}(=\mathrm{O}) \mathrm{O}) \mathrm{O}) \mathrm{F}) \mathrm{O}) \mathrm{F}$ & -6.1 & -7.4 & -6.6 & -7.1 & -7.4 & -6.4 & -7.9 & -6.2 & -6 \\
\hline 117299852 & $C 1=C(C(=C C(=C 1 C(=0) O) O) O) C C C=O$ & -6.3 & -7.1 & -6.5 & -6.4 & -6.7 & -6.7 & -7.5 & -6.3 & -6.5 \\
\hline 117302638 & $\mathrm{C} 1=\mathrm{C}(\mathrm{C}(=\mathrm{CC}(=\mathrm{C} 1 \mathrm{C}(=\mathrm{O}) \mathrm{O}) \mathrm{O}) \mathrm{O}) \mathrm{CCCO}$ & -6 & -7.2 & -6.6 & -6.6 & -6.8 & -6.6 & -7.3 & -6.2 & -6.6 \\
\hline 117324768 & $C 1=C(C(=C C(=C 1 C(=0) O) O) O) C C C(=0) O$ & -6 & -8 & -7 & -6.9 & -7.5 & -7 & -7.6 & -6.5 & -6.1 \\
\hline 118453489 & $C=C(C 1=C 2 C=C C=C 2 C=C 1) C(=O) N$ & -7.6 & -8.6 & -8.5 & -8.1 & -8.2 & -7.4 & -9.2 & -6.4 & -6.3 \\
\hline 121007170 & $\mathrm{C} 1 \mathrm{C}=\mathrm{CC} 1 \mathrm{CCC} 2=\mathrm{CC}=\mathrm{CC}=\mathrm{C} 2$ & -7.4 & -8.4 & -8.4 & -8.3 & -7.6 & -6.6 & -8.4 & -6.5 & -6.3 \\
\hline 121220525 & $\mathrm{CCCC} 1 \mathrm{C} 2=\mathrm{CC}=\mathrm{CC}=\mathrm{C} 2 \mathrm{C} 1=\mathrm{O}$ & -6.6 & -8.2 & -7.7 & -8 & -7.8 & -6.5 & -8.1 & -6 & -6.2 \\
\hline 121282030 & $\mathrm{CC} 1 \mathrm{CCCC} 1 \mathrm{C} 2=\mathrm{CC}=\mathrm{CC}=\mathrm{C} 2 \mathrm{OO}$ & -6 & -8 & -7.2 & -7.6 & -7.5 & -6.7 & -8.6 & -6.1 & -6.3 \\
\hline 121394326 & $\operatorname{CcCC}(=O) C 1=N C=C(C=C 1) C$ & -6.5 & -8.1 & -7.3 & -7.5 & -7 & -6 & -7.4 & -6.5 & -6 \\
\hline 121454529 & $\mathrm{C} 1 \mathrm{CC} 1 \mathrm{C} 2 \mathrm{CC} 3=\mathrm{CC}=\mathrm{CC}=\mathrm{C} 3 \mathrm{O} 2$ & -7.1 & -7.9 & -7.8 & -7.9 & -7.8 & -6.6 & -8.4 & -6.3 & -6 \\
\hline 123264162 & $\mathrm{C} 1 \mathrm{CC} 2 \mathrm{C} 1 \mathrm{C} 3=\mathrm{CC}=\mathrm{CC}=\mathrm{C} 3 \mathrm{O} 2$ & -6 & -7.6 & -7.4 & -7.7 & -7.3 & -6.1 & -7.7 & -6.1 & -7.6 \\
\hline 126986684 & C\#CCCC(=O)N[C@@H]1CC[C@H]1O & -6.2 & -7.4 & -6.7 & -6.9 & -6.6 & -6.1 & -6.9 & -6.1 & -6.1 \\
\hline 129653236 & $C C(=C=C(C 1=C C=C C=C 1) O) O$ & -7.8 & -8.3 & -8 & -7.9 & -7.5 & -6.5 & -8.1 & -6.7 & -6.3 \\
\hline 129738993 & $\mathrm{C} 1=\mathrm{CC} 2=\mathrm{C} 3 \mathrm{C}(=\mathrm{C} 1) \mathrm{OC} 3=\mathrm{NC} 2=\mathrm{O}$ & -6.2 & -7.9 & -6.3 & -6.9 & -7.2 & -6.5 & -7.5 & -7 & -7.3 \\
\hline 129911228 & $\mathrm{C} 1=\mathrm{C}(\mathrm{OC}(=\mathrm{C} 1) \mathrm{S}(=\mathrm{O})(=\mathrm{O}) \mathrm{N})[\mathrm{N}+](=\mathrm{O})[\mathrm{O}-]$ & -6.1 & -7.5 & -6.3 & -6 & -6.7 & -6.1 & -6.8 & -6.9 & -6.1 \\
\hline 130131264 & $\mathrm{CC}(\mathrm{C}) \mathrm{C} 1=\mathrm{CC}=\mathrm{CC}(\mathrm{C}(=\mathrm{C} 1) \mathrm{O}) \mathrm{O}$ & -6.6 & -7.1 & -7.5 & -7.5 & -7.6 & -6.7 & -7.9 & -6.1 & -6 \\
\hline
\end{tabular}




\begin{tabular}{|c|c|c|c|c|c|c|c|c|c|c|}
\hline 130142273 & $\mathrm{C} 1 \mathrm{C} 2 \mathrm{CC} 3=\mathrm{CC}=\mathrm{CC}=\mathrm{C} 3 \mathrm{C} 2 \mathrm{C} 1 \mathrm{O}$ & -6.3 & -7.8 & -7.7 & -7.6 & -7 & -6.5 & -8.5 & -6.5 & -6.8 \\
\hline 130142771 & $C C / C=C / C(C 1 C=C C(=0) 01) O$ & -6.8 & -7.1 & -7 & -7 & -6.9 & -6 & -7.2 & -7.1 & -6.1 \\
\hline 130427856 & $\mathrm{C}[\mathrm{C} @ @ \mathrm{H}](\mathrm{CC} 1=\mathrm{CC}(=\mathrm{C}(\mathrm{C}=\mathrm{C} 1) \mathrm{O}) \mathrm{O}) \mathrm{OC}$ & -6.2 & -7.5 & -7.2 & -6.6 & -7.3 & -6.3 & -7.2 & -6.6 & -6.3 \\
\hline 130669129 & $\mathrm{CCC}(\mathrm{C}) \mathrm{C}(=\mathrm{O}) \mathrm{N}[\mathrm{C} @ @ \mathrm{H}] 1 \mathrm{CC}[\mathrm{C} @ \mathrm{H}] 10$ & -6.5 & -7.5 & -7 & -7 & -6.8 & -6 & -7.1 & -6.1 & -6 \\
\hline 130671082 & $\mathrm{C} 1=\mathrm{CC}=\mathrm{C}(\mathrm{C}=\mathrm{C} 1) \mathrm{C}(=\mathrm{O})[\mathrm{C} @ \mathrm{H}](\mathrm{CO}) \mathrm{O}$ & -6.4 & -7.8 & -7.5 & -7.5 & -7 & -6.4 & -7.2 & -6.4 & -6.6 \\
\hline 130717007 & CC1CC1CC(=O)N[C@@H]2CC[C@H]2O & -6.5 & -7.8 & -7.6 & -7.4 & -7.2 & -6.7 & -8 & -6.9 & -6.6 \\
\hline 130818495 & $\mathrm{CC} 1=\mathrm{CC}(=\mathrm{C}(\mathrm{C}=\mathrm{C} 1) \mathrm{O}) \mathrm{C}(=\mathrm{O}) \mathrm{C}[\mathrm{C} @ @ \mathrm{H}](\mathrm{C}) \mathrm{O}$ & -6.9 & -8.6 & -7.9 & -7.4 & -7.2 & -6.6 & -8.2 & -6.3 & -6 \\
\hline 130899233 & C1CCC(C1)C(=O)N[C@@H]2CC[C@H]2O & -7 & -8.1 & -7.5 & -7.8 & -7.3 & -6.4 & -7.9 & -6.6 & -6.2 \\
\hline 131071844 & $\mathrm{C} 1 \mathrm{CC} 2=\mathrm{CC}=\mathrm{CC}=\mathrm{C} 2 \mathrm{CCC} 1 \mathrm{NN}$ & -6 & -7.8 & -7.6 & -7.9 & -7 & -7.5 & -9.3 & -6.2 & -6.5 \\
\hline 131093170 & CCC[C@@H]1CC[C@H](N1)C(=O)O & -6 & -6.8 & -6.2 & -6.2 & -6.4 & -6.2 & -6.7 & -6.8 & -6.5 \\
\hline 131178805 & $\mathrm{CCC}(=\mathrm{O}) \mathrm{N}[\mathrm{C} @ @ \mathrm{H}] 1 \mathrm{CCCC}[\mathrm{C} @ \mathrm{H}] 1 \mathrm{~F}$ & -6 & -7 & -6.6 & -6.4 & -7.1 & -6.3 & -7 & -6.1 & -6 \\
\hline 131385444 & $C C=C C 1=C(C(=C C(=C 1) O) O) O$ & -6.6 & -7.3 & -6.9 & -6.8 & -7.3 & -6.3 & -7.1 & -7.1 & -6 \\
\hline 131408804 & $C 1 C C 1 C C 2=C(C(=C C=C 2) O) O$ & -6.9 & -7.6 & -7.1 & -7.1 & -7.6 & -6.2 & -7.4 & -6.4 & -6.8 \\
\hline 131468705 & $\mathrm{CC}(\mathrm{C}(\mathrm{CC} 1=\mathrm{CC}(=\mathrm{CC}=\mathrm{C} 1) \mathrm{O}) \mathrm{O}) \mathrm{O}$ & -6.5 & -7.5 & -7.5 & -6.8 & -7.6 & -6.2 & -7.6 & -6.2 & -6.4 \\
\hline 132564184 & $\mathrm{CC}(\mathrm{CCC} 1=\mathrm{C}(\mathrm{C}(=\mathrm{CC}=\mathrm{C} 1) \mathrm{O}) \mathrm{O}) \mathrm{O}$ & -6.2 & -7.8 & -7 & -6.8 & -7.8 & -6 & -7.3 & -6.5 & -6.2 \\
\hline 134902841 & $\mathrm{C}=\mathrm{CC} 1 \mathrm{CC} 2 \mathrm{CC} 1 \mathrm{C} 3=\mathrm{CCC}=\mathrm{C} 23$ & -6.9 & -8 & -7.7 & -7.6 & -7.7 & -6.3 & -7.5 & -6.2 & -6.3 \\
\hline
\end{tabular}

Unit of the free binding energy, $\mathrm{kCal} / \mathrm{mol}$ 